OPEN ACCESS

Edited by:

Marina De Bernard,

University of Padova, Italy

Reviewed by:

Luís Jaime Mota,

New University of Lisbon, Portugal

Susan M. Bueno,

Pontifical Catholic University of

Chile, Chile

*Correspondence:

Arunika Mukhopadhaya

arunika@iisermohali.ac.in

Specialty section: This article was submitted to

Microbial Immunology,

a section of the journal

Frontiers in Immunology

Received: 24 August 2019 Accepted: 15 November 2019 Published: 10 December 2019

Citation:

Gulati A, Shukla R and Mukhopadhaya A (2019) Salmonella

Effector SteA Suppresses Proinflammatory Responses of the Host by Interfering With $I_{\kappa} B$

Degradation.

Front. Immunol. 10:2822

doi: 10.3389/fimmu.2019.02822

\section{Salmonella Effector SteA Suppresses Proinflammatory Responses of the Host by Interfering With IкB Degradation}

\author{
Aakanksha Gulati, Rhythm Shukla and Arunika Mukhopadhaya* \\ Department of Biological Sciences, Indian Institute of Science Education and Research Mohali, Sahibzada Ajit \\ Singh Nagar, India
}

Salmonella enterica serovar Typhimurium is known to cause its virulence by secreting various effector proteins directly into the host cytoplasm via two distinct type III secretion systems (T3SS-1 and T3SS-2). Generally, T3SS-1-delivered effectors help Salmonella Typhimurium in the early phases of infection including invasion and immune modulation of the host cells, whereas T3SS-2 effectors mainly help in the survival of Salmonella Typhimurium within the host cells including maintenance of Salmonella-containing vacuole, replication of the bacteria, and dissemination. Some of the effectors are secreted via both T3SS-1 and T3SS-2, suggesting their role in distinct phases of infection of host cells. SteA is such an effector that is secreted by both T3SS-1 and T3SS-2. It has been shown to control the membrane dynamics of the Salmonella-containing vacuole within the host cells in the late phases of infection. In this manuscript, toward characterizing the T3SS-1 function of SteA, we found that SteA suppresses inflammatory responses of the host by interfering with the nuclear factor kappa B pathway. Our initial observation showed that the mice infected with steA-deleted Salmonella Typhimurium $(\Delta s t e A)$ died earlier compared to the wild-type bacteria due to heightened immune responses, which indicated that SteA might suppress immune responses. Furthermore, our study revealed that SteA suppresses immune responses in macrophages by interfering with the degradation of $1 \kappa \mathrm{B}$, the inhibitor of nuclear factor kappa B. SteA suppresses the ubiquitination and hence degradation of $\mathbf{l}_{\kappa} \mathrm{B}$ by acting on Cullin-1 of the Skp-1, Cullin-1, F-box (SCF)-E3 ligase complex. Our study revealed that SteA suppresses a key step necessary for E3 ligase activation, i.e., neddylation of Cullin-1 by interfering with dissociation of its inhibitor Cand-1.

Keywords: Salmonella enterica serovar Typhimurium, SteA, proinflammatory responses, IкB degradation, E3 ligase

\section{INTRODUCTION}

Salmonella enterica serovar Typhimurium utilizes diverse strategies to subvert host defenses by translocating various effectors via a specialized needle-like complex called the type III secretion system (T3SS) $(1,2)$. The Salmonella T3SSs are encoded by small stretches of chromosomes known as Salmonella pathogenicity island-1 (SP-1; encoding T3SS-1) and SPI-2 (encoding T3SS-2) (2-5). The T3SS effectors are either encoded or regulated by the SPI-1 or SPI-2 (6). The effectors modulate 
different functions of the host and help the bacteria to invade, survive, and replicate in the host cell (5-9).

Before the Salmonella enters into the host cell, the T3SS-1 is assembled by the bacteria across the host cell membrane. It generally translocates effectors, which are required for invasion and modulation of host immune responses. T3SS-1 effectors, such as SipA and SipC, bind to actin and help the bacteria in invasion (10-12); SopE and SopE2 modulate both actin rearrangement and host immune responses (13-15). Upon invasion, Salmonella-containing vacuoles (SCVs) are formed inside the host cell cytoplasm. Within the SCVs, bacteria replicate. T3SS-2 is formed across the SCV membrane, and the effectors are secreted into the host cell cytoplasm. T3SS2 effectors are majorly required for maintenance of SCV and replication and spread of the bacteria $(4,7)$. For example, SifA helps in the formation of Salmonella-induced filaments (SIF) (16-18). SIFs connect the SCV to various organelles like ER, Golgi, etc. of the cell, thereby expanding the replicative niche and acquiring nutrients for the replication of Salmonella (19-21).

In addition, some of the effectors such as SpvD, SlrP, SteE, SteB, GtgE, etc. are regulated by both SPI-1 and SPI-2 and translocated by both T3SS-1 and T3SS-2, indicating their role in both early and later phases of infection $(22,23)$. SteA is one such effector molecule (24). Using Nramp1 mice, Lawley et al. have shown that SteA might play a role in the replication of Salmonella (25). Geddes et al. have reported that SteA could localize in the trans-Golgi network (22). However, Van Engelenburg and Palmer have later indicated that SteA could localize in Salmonella-induced tubules enriched with the transGolgi protein GalT (26). Furthermore, Domingues et al. have reported that, in the later phases of infection, SteA binds to phosphatidylinositol 4-phosphate [PI(4)P] to control membrane dynamics of SCV, thereby helping Salmonella to localize within SCV and in Salmonella-induced tubules $(27,28)$. Matsuda et al. have indicated that SteA could induce T3SS-1-independent inflammation and cytotoxicity in macrophages (29). McQuate et al. have reported that SteA is important for establishing infection in the early phase and in the prevention of the clearance of Salmonella from macrophages (30). However, the SPI-1-regulated role of SteA in Salmonella infection is yet to be fully established.

In this study, toward unraveling the T3SS-1 role of SteA, we have shown that SteA suppresses the proinflammatory responses induced due to Salmonella Typhimurium infection. We observed that SteA interferes with the activation of nuclear factor kappa B $(\mathrm{NF}-\kappa \mathrm{B})$, which is one of the major transcription factors known to be involved in the generation of proinflammatory responses. NF$\kappa \mathrm{B}$ in its inactive state remains in the cytoplasm bound with its inhibitor I $\mathrm{B}$. I $\mathrm{B}$ B degradation is necessary for NF- $\kappa \mathrm{B}$ activation and is mediated by its ubiquitination. The E3 ligase is responsible for the ubiquitination of IкB (31). Our study revealed that SteA inhibits activation of Cullin-1, a component of E3 ligase complex and hence ubiquitination and degradation of ІкB.

Abbreviations: $\triangle$ steA, deletion mutant of steA gene; compl, steA complemented in the $\triangle$ steA background; compl-H, 6X His-tagged steA complemented in the $\Delta$ ste $A$ background.

\section{MATERIALS AND METHODS}

\section{Ethics Statement}

All animal experiments were carried out in accordance with the guidelines of the Committee for the Purpose of Control and Supervision of Experiments on Animals (No. 1842/GO/ReBiBt/S/15/CPCSEA). All the protocols for animal handling were approved by the Institutional Animals Ethics Committee of Indian Institute of Science Education and Research, Mohali (IISERM/SAFE/PRT/2016-2018/004, 010, 015).

\section{Bacterial Strains}

S. enterica serovar Typhimurium SL1344 strain was a kind gift from Dr. Mahak Sharma (IISER Mohali). SteA in the genome of Salmonella Typhimurium was replaced with a Kanamycin cassette by one-step inactivation method following the protocol by Datsenko and Warner (32). Briefly, Kanamycin cassette was amplified from the plasmid pKD13 (a kind gift from Dr. Rachna Chaba, IISER Mohali) using primers-SteA H1P2 and SteA H2P1 (Table 1). The amplified Kanamycin cassette with flanking regions corresponding to the flanking regions of the steA gene in the Salmonella Typhimurium genome was transformed into Salmonella Typhimurium expressing the $\lambda$-red recombinase via the helper plasmid pKD46 (a kind gift from Dr. Rachna Chaba, IISER Mohali). The colonies were selected on Kanamycin plates and screened by colony PCR. The deletion mutant of $\triangle$ steA was then transduced to a clean background (Salmonella Typhimurium SL1344) using P22 phage (a kind gift from Dr. Rachna Chaba, IISER Mohali). For complementation, steA gene of Salmonella Typhimurium (www.ncbi.nlm.gov.in) was cloned in pACYC177 (a kind gift from Dr. Rachna Chaba, IISER Mohali) using restriction cloning and was transformed in the deletion mutant of SteA $(\triangle$ steA) background. The $\Delta$ spi2 Salmonella Typhimurium 14028 (SV6017) strain was a kind gift from Dr. Francisco Ramos-Morales (University of Seville, Spain) (33). The P22 phage transduction method was used to construct $\Delta$ spi2 SL1344 and $\Delta$ spi2 $\Delta$ steA SL1344 strains. The primers used in this study are listed in Table 1, and the strains and plasmids used in this study are listed in Table 2.

\section{Cell Lines and Culture Conditions}

RAW 264.7 (a murine macrophage cell line) used in this study was obtained from the National Center for Cell Science, Pune, India, and HEK 293 (a human kidney epithelial cell line) was obtained from American Type Culture Collection. The cells were maintained, respectively, in Roswell Park Memorial Institute (RPMI) 1640 or Dulbecco's modified Eagle medium (DMEM) supplemented with $10 \%(v / v)$ fetal bovine serum (FBS), $100 \mathrm{U} / \mathrm{ml}$ of penicillin, and $100 \mu \mathrm{g} / \mathrm{ml}$ of streptomycin (Invitrogen, Life Technologies, USA) at $37^{\circ} \mathrm{C}$ and $5 \% \mathrm{CO}_{2}$.

\section{Differentiation of Bone Marrow Cells to Bone-Marrow-Derived Macrophages}

$\mathrm{Balb} / \mathrm{c}$ mice 6-8 weeks old were euthanized, and their femur and tibia bones were extracted. The muscle tissue of the bones was then removed off and were then washed with ice-cold phosphate-buffered saline (PBS). They were then dipped in 
TABLE 1 | Primers used in this study.

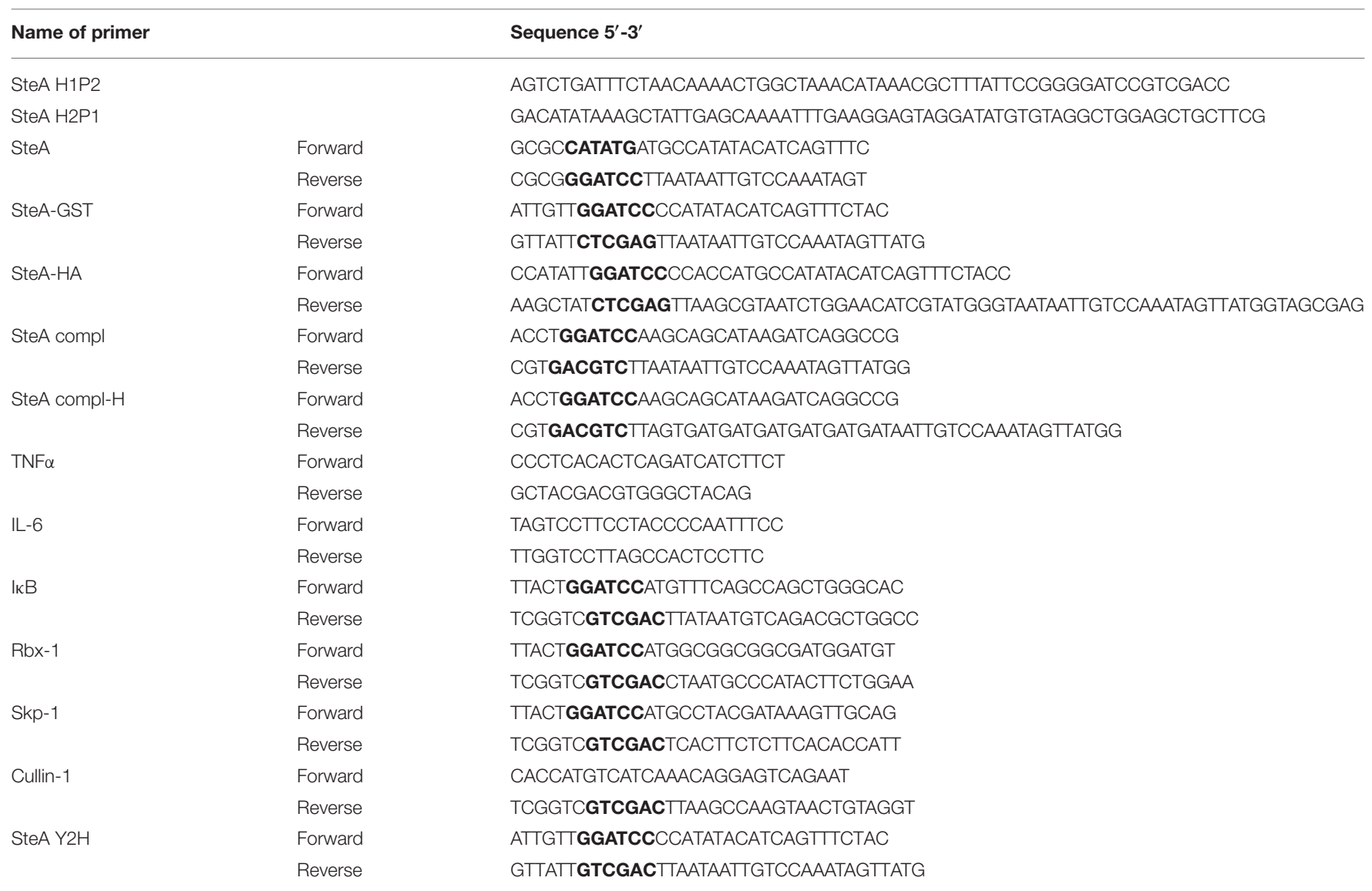

*The highlighted regions indicate the restriction sites.

$70 \%(v / v)$ alcohol for $2 \mathrm{~min}$ and were transferred to RPMI 1640 media. Then, using sterile scissors, the epiphyses of the bones were cut, and the bone marrow cells were extracted by flushing the bones with RPMI 1640 media. These bone marrow cells were then differentiated to bone-marrow-derived macrophages (BMDMs) using macrophage colony-stimulating factor (M-CSF). Briefly, cells were suspended in differentiation media [RPMI 1640 supplemented with 10\% $(v / v)$ FBS, $100 \mathrm{U} / \mathrm{ml}$ of Penicillin, $100 \mu \mathrm{g} / \mathrm{ml}$ of Streptomycin, $1 \mathrm{mM}$ sodium pyruvate, $0.1 \mathrm{mM}$ nonessential amino acids, $1 \%(v / v) \beta$-mercaptoethanol, and $20 \mathrm{ng} / \mathrm{ml}$ of $\mathrm{M}-\mathrm{CSF}$ ] and plated in 24-well plates. They were incubated at $37^{\circ} \mathrm{C}$ with $5 \% \mathrm{CO}_{2}$. The media were changed every 2 days, and fresh differentiation media was added. The adhered cells obtained at day 7 were BMDMs and were used for further experiments.

\section{Infection of Cells}

For inducing SPI-1 conditions, as described previously by Cardenal-Munoz and Ramos-Morales (24), bacteria were grown to stationary phase in Luria-Bertani (LB) broth supplemented with $0.3 \mathrm{M} \mathrm{NaCl}$ and appropriate antibiotics. Cells were plated in 24- or 6-well plates at a density of $1 \times 10^{6}$ cells $/ \mathrm{ml}$ for overnight and infected with the stationary phase bacteria at a multiplicity of infection (MOI) of 10:1 (for BMDMs) or 20:1 (for RAW 264.7 and HEK 293 cells) for $30 \mathrm{~min}$. The media containing the bacteria was removed, and fresh media supplemented with $100 \mu \mathrm{g} / \mathrm{ml}$ of gentamicin were added to the wells. After $1 \mathrm{~h}$, this media was replaced with fresh media supplemented with $20 \mu \mathrm{g} / \mathrm{ml}$ of gentamicin for different time points depending on the assay. In all the experiments, the invasion was checked after $2 \mathrm{~h}$ of infection by enumerating the bacteria after the cells were lysed with $0.1 \%$ $(v / v)$ Triton-X-100 (Himedia, India) in PBS.

\section{Cell Cytotoxicity Assay}

RAW 264.7 and BMDMs were plated at a density of $1 \times 10^{6}$ cells/ml and infected with wild type (wt), $\Delta$ steA, or compl strains at an MOI of 20:1 or 10:1, respectively. After $8 \mathrm{~h}$ of infection, supernatants were collected, and cell cytotoxicity was checked using lactate dehydrogenase release assay (Promega, USA), according to the manufacturer's protocol.

\section{Mice Infection and Scoring}

Bacteria grown overnight in LB medium supplemented with $50 \mu \mathrm{g} / \mathrm{ml}$ of streptomycin were subcultured and grown until log phase at $37^{\circ} \mathrm{C}$. Balb/c mice $6-8$ weeks old were infected intraperitoneally with $5 \times 10^{5}$ or $5 \times 10^{7} \log$-phase bacteria, and the survival of mice was monitored for 24 and $96 \mathrm{~h}$, respectively. $p$ values were calculated using Kaplan-Meir test using the software R. In addition, $36 \mathrm{~h}$ postinfection (hpi), the 
TABLE 2 | Strains and plasmids used in this study.

\begin{tabular}{|c|c|c|}
\hline Strains Salmonella Typhimurium & Genotype or description & Reference \\
\hline wt & Wild-type SL1344 & A kind gift from Dr. Mahak Sharma \\
\hline$\Delta s t e A$ & ste $A:: \mathrm{Km}^{\mathrm{R}}$ & This study \\
\hline compl & steA::Km, pACYC177-steA & This study \\
\hline compl-H & steA::Km ${ }^{R}$ pACYC177-steA-His & This study \\
\hline 14028 sspi2 (SV6017) & spi2::Cm $\mathrm{Cm}^{\mathrm{R}}$ & A kind gift from Dr. Francisco Ramos-Morales \\
\hline SL1344 $\Delta$ spi2 & spi2:: $\mathrm{Cm}^{\mathrm{R}}$ & This study \\
\hline$\Delta$ spi2 $\Delta$ steA & spi2:: $\mathrm{Cm}^{\mathrm{R}}$, steA:: $\mathrm{Km}^{\mathrm{R}}$ & This study \\
\hline Plasmids & Description & Reference \\
\hline pKD13 & Template used for amplifying Kanamycin Cassette & A kind gift from Dr. Rachna Chaba \\
\hline pKD46 & Plasmid expressing $\lambda$-red recombinase & A kind gift from Dr. Rachna Chaba \\
\hline pACYC177 & Bacterial expression plasmid used for complementation & A kind gift from Dr. Rachna Chaba \\
\hline pACYC177-steA & steA with its native promoter cloned in pACYC177 & This study \\
\hline pACYC177-steA-His & His-tagged steA with its native promoter cloned in pACYC177 & This study \\
\hline pGEX4T3 & Plasmid expressing GST & A kind gift from Dr. Mahak Sharma \\
\hline pGEX4T3-steA & Plasmid expressing GST-tagged SteA & This study \\
\hline pcDNA3.1(+) & Mammalian expression plasmid & A kind gift from Dr. Kausik Chattopadhyay \\
\hline pcDNA3.1(+)steA & Mammalian expression plasmid expressing HA-tagged SteA & This study \\
\hline pGL4.32 & NF-кB promoter reporter plasmid & Promega, USA \\
\hline $\mathrm{pRL}$ & Plasmid expressing renilla luciferase & A kind gift from Dr. Rajesh Ramachandran \\
\hline pGADC1 & Yeast expression plasmid with activation domain (AD) & A kind gift from Dr. Shravan Mishra \\
\hline $\mathrm{pGADC1} 1-\kappa_{\kappa} B$ & Yeast expression plasmid with activation domain (AD) fused with $\mathbf{I}_{\kappa} B$ & This study \\
\hline pGADC1-Rbx1 & Yeast expression plasmid with activation domain (AD) fused with Rbx-1 & This study \\
\hline pGADC1-Skp1 & Yeast expression plasmid with activation domain (AD) fused with Skp-1 & This study \\
\hline pGADT7 & Yeast expression plasmid with activation domain (AD) & A kind gift from Dr. Ram K. Yadav \\
\hline pGADT7-Cullin 1 & Yeast expression plasmid with activation domain (AD) fused with Cullin-1 & This study \\
\hline pGBDUC1 & Yeast expression plasmid with binding domain (BD) & A kind gift from Dr. Shravan K. Mishra \\
\hline pGBDUC1-steA & Yeast expression plasmid with binding domain (BD) fused with SteA & This study \\
\hline
\end{tabular}

mice infected with $5 \times 10^{5}$ bacteria were scored for their response to stimuli, the extent of decrease in activity, the extent of eye closure and the pilorected fur as compared to the uninfected mice as described previously by Shrum et al. (34). In addition, the core body temperature of mice was checked using a noncontact infrared thermometer at $24 \mathrm{~h}$ after infection with $5 \times 10^{5}$ bacteria. The body temperature of mice was also checked before infection, and the difference in temperature of each mice was calculated. The blood of infected mice was collected at 24 and $36 \mathrm{~h}$ after infection, and serum was isolated from it. The serum was analyzed for tumor necrosis factor alpha $(\mathrm{TNF} \alpha)$, interleukin (IL)-6, IL-1 $\beta$, interferon gamma (IFN- $\gamma$ ), IL12, and IL-10 (BD Biosciences, USA) using ELISA according to manufacturer's protocol.

\section{Colonization and Splenic Lysate Preparation}

$\mathrm{Balb} / \mathrm{c}$ mice 6-8 weeks old were infected intraperitoneally with $5 \times 10^{5} \log$-phase bacteria. At $36 \mathrm{hpi}$, spleens were isolated and homogenized in PBS using a sterile pestle.

For colonization, the homogenate was subjected to lysis with $0.1 \%(v / v)$ Triton-X-100 at $37^{\circ} \mathrm{C}$ for $30 \mathrm{~min}$. The bacteria were enumerated after serial dilution on LB agar (LA) plates supplemented with $50 \mu \mathrm{g} / \mathrm{ml}$ of streptomycin.
For splenic lysate preparation, the homogenate was pelleted by centrifugation at $2,000 \times g$ for $5 \mathrm{~min}$ and washed twice with PBS. Then, the pellet was treated with $500 \mu \mathrm{l}$ of ACK lysis buffer [154.95 $\mathrm{mM} \mathrm{NH}_{4} \mathrm{Cl}, 10 \mathrm{mM} \mathrm{KHCO}_{3}$, and $0.1 \mathrm{mM}$ ethylenediaminetetraacetic acid (EDTA); $\mathrm{pH}$ 7.2] at room temperature for $5 \mathrm{~min}$. To stop the reaction, $100 \mu \mathrm{l}$ of FBS was added to it and was centrifuged at $2,000 \times g$ for $5 \mathrm{~min}$ and washed twice with PBS. The pellet was then resuspended in 70 $\mu \mathrm{l}$ of RIPA buffer [50 mM Tris-Cl (pH 8), $150 \mathrm{mM} \mathrm{NaCl}, 5 \mathrm{mM}$ EDTA, 1\% $(v / v)$ NP-40, 0.5\% $(w / v)$ sodium deoxycholate, and $0.1 \%(w / v)$ sodium dodecyl sulfate] containing $1 \times$ mammalian protease inhibitor cocktail (Sigma-Aldrich, USA) and sonicated at $10 \AA$ for three pulses of $5 \mathrm{~s}$ each. This was then centrifuged at $24,000 \times g$ for $30 \mathrm{~min}$. The supernatant thus obtained was the splenic lysate.

\section{TNF $\alpha$ and IL-6 Gene Expression}

$\mathrm{Balb} / \mathrm{c}$ mice 6-8 weeks old were infected intraperitoneally with $5 \times 10^{5}$ log-phase bacteria. At $36 \mathrm{hpi}$, spleens were isolated and were subjected to ballooning with $400 \mathrm{U} / \mathrm{ml}$ Collagenase $\mathrm{D}$ in $\mathrm{HBSS}$ and incubated at $37^{\circ} \mathrm{C}$ for $25 \mathrm{~min}$. To stop the reaction, $100 \mu \mathrm{l}$ of $0.5 \mathrm{M}$ EDTA was added and incubated at $37^{\circ} \mathrm{C}$ for $5 \mathrm{~min}$. This was then passed through a $40-\mu \mathrm{m}$ strainer, and $5 \mathrm{ml}$ of ice-cold RPMI 1640 media supplemented 
with $10 \%(v / v)$ FBS was added to it. The cells were then harvested at $2,000 \times g$ for $5 \mathrm{~min}$ and washed with PBS. The pellet was resuspended in $3 \mathrm{ml}$ of $30 \%$ bovine serum albumin (Sigma-Aldrich, USA). To this, $1 \mathrm{ml}$ of PBS was added slowly along the wall of the conical tube to form a layer and was subjected to density gradient centrifugation (with zero acceleration or deceleration) at $2,200 \times g$ for $30 \mathrm{~min}$ at $12^{\circ} \mathrm{C}$. The interface of the two layers contained the mononuclear cells, which were then harvested, and RNA was isolated according to the manufacturer's protocol using the Nucleopore RNA isolation Kit (Genetix, India). The complementary DNA (cDNA) was then synthesized using Verso-cDNA kit (Thermo-Fisher, USA). The PCRs were performed using Maxima SYBR green qPCR master mix (Thermo-Fisher, USA) and the Eppendorf Realplex master cycler. Primer sequences were used from the Harvard primer bank and were synthesized by Integrated DNA Technologies, USA.

\section{Quantification of TNF $\alpha$}

RAW 264.7 and BMDMs were plated at a density of $1 \times$ $10^{6}$ cells $/ \mathrm{ml}$ and infected with wt, $\Delta$ steA, or compl strains at an MOI of $20: 1$ or $10: 1$, respectively. The supernatant was collected after $8 \mathrm{~h}$ of infection, and $\mathrm{TNF} \alpha$ was quantified using ELISA (BD Biosciences, USA) as per the manufacturer's protocol. Furthermore, to confirm equal invasion in all the experiments, cells were lysed after $2 \mathrm{~h}$ of infection with $0.1 \%(v / v)$ Triton$\mathrm{X}-100$ at $37^{\circ} \mathrm{C}$ for $30 \mathrm{~min}$, and bacteria were enumerated on LA plates.

\section{Transfection of HEK 293 Cells}

HEK 293 (a human kidney epithelial cell line) cells $(7 \times$ $10^{6}$ ) were plated in DMEM in a 90-mm Petri dish for wholecell lysate preparation, and $2.5 \times 10^{4}$ HEK 293 cells were seeded on coverslips in a 24-well plate for colocalization studies. Cells were then transfected with $3 \mu \mathrm{g}$ (for wholecell lysates) or $1 \mu \mathrm{g}$ (for colocalization) of pCDNA3.1(+) or pCDNA3.1 $(+)$ steA (Table 2) using polyethyleneimine at a ratio of 1:3 (DNA/polyethyleneimine). The media was changed after $8 \mathrm{~h}$ of transfection. Then, after 24 or $36 \mathrm{~h}$ of transfection, the cells were stimulated with $10 \mathrm{ng} / \mathrm{ml}$ of $\mathrm{TNF} \alpha$ for 15 or $30 \mathrm{~min}$ for whole-cell lysate preparation and $30 \mathrm{~min}$ for colocalization studies.

\section{Luciferase Reporter Assay For HEK 293 Cells}

HEK 293 cells $\left(2.5 \times 10^{4}\right)$ were plated in $100 \mu \mathrm{l}$ of DMEM in a 96-well plate and were transfected with $0.1 \mu \mathrm{g}$ each of NF- $\kappa \mathrm{B}$ reporter plasmid pGL4.1 (Promega, USA) and renilla luciferase plasmid (pRL) (Table 2) using Lipofectamine 3000 (Promega, USA) as per the manufacturer's protocol. In addition, in assays for studying the effect of endogenous expression of SteA on NF$\kappa \mathrm{B}$ activation, cells were also transfected with pcDNA3.1(+) or pcDNA3.1(+)steA in addition to pGL4.32 and pRL. After $18 \mathrm{~h}$ of transfection, the cells were either infected with wt, $\Delta$ steA, and compl or stimulated with $10 \mathrm{ng} / \mathrm{ml}$ of $\mathrm{TNF} \alpha$ for 6 and $8 \mathrm{~h}$, respectively.

\section{For RAW 264.7 Cells}

RAW 264.7 cells $\left(5 \times 10^{4}\right)$ were plated in $100 \mu$ l of RPMI in a 96-well plate and were transfected with $0.15 \mu \mathrm{g}$ each of NF$\kappa \mathrm{B}$ reporter plasmid pGL4.1 (Promega, USA) and pRL (Table 2) using FuGene HD (Promega, USA) as per the manufacturer's protocol. After $12 \mathrm{~h}$ of transfection, the cells were infected with wt, $\triangle$ steA, and compl or stimulated with $500 \mathrm{ng} / \mathrm{ml}$ of LPS for $15 \mathrm{~h}$.

The dual luciferase assay kit (Promega, USA) was used according to the manufactures' protocol to analyze the luminescence corresponding to NF- $\mathrm{B}$ activation (firefly luciferase) and the renilla luciferase. The luminescence was detected using a plate reader (BMG Biotech, Germany). The luminescence corresponding to NF- $\kappa \mathrm{B}$ activation was normalized to that of renilla luciferase (corresponding to the transfection efficiency). In infection-based experiments, the luminescence was also normalized to the invasion.

\section{Colocalization Studies}

After $24 \mathrm{~h}$ of transfection in HEK 293 cells and TNF $\alpha$ stimulation for $30 \mathrm{~min}$ (as described previously), cells were washed twice with PBS and were then fixed with $2.5 \%(w / v)$ of paraformaldehyde for $30 \mathrm{~min}$ at room temperature. Cells were then washed twice with PBS and incubated with anti-IкB (1:750) (Santa Cruz Biotechnologies, USA), anti-HA (1:250) (Biolegend, USA), anti-Cullin-1 (1:250) (Cell Signaling Technologies, USA), or anti-Cand-1 (1:500) (Cell Signaling Technologies, USA) antibodies for $45 \mathrm{~min}$ at room temperature. Then, cells were washed thrice with PBS and incubated with Alexa 488conjugated anti-rabbit immunoglobulin G secondary antibody (1:500) (Life Technologies, USA) and Alexa 568-conjugated anti-mouse immunoglobulin G secondary antibody (1:500) (Life Technologies, USA) for $30 \mathrm{~min}$ at room temperature. All the antibody dilutions were prepared in $0.2 \%(w / v)$ Saponin dissolved in PBS. The cells were washed thrice with PBS and were mounted on glass slides using Fluoromount (Sigma-Aldrich, USA). The imaging was performed using a Zeiss confocal microscope (for colocalization of IкB or Cullin-1 with SteAHA) or Leica confocal microscope (for colocalization of Cand-1 with SteA-HA).

\section{Whole-Cell Lysate Preparation For Infection}

Cells were plated at a density of $1.5 \times 10^{6} / \mathrm{ml}$ in a six-well plate for overnight. Cells $\left(4.5 \times 10^{6}\right)$ (three wells of $\left.1.5 \times 10^{6} / \mathrm{ml}\right)$ were infected with wt, $\Delta s t e A$, or compl for $30 \mathrm{~min}$. Then, the bacteria were removed, and RPMI 1640 media containing $100 \mu \mathrm{g} / \mathrm{ml}$ of gentamicin was added to each well for $30 \mathrm{~min}$. The cells were then washed twice with sterile PBS and were then harvested at $2,000 \times g$ for $5 \mathrm{~min}$. The pellet was then resuspended in 70-100 $\mu \mathrm{l}$ of whole-cell lysis buffer [ $50 \mathrm{mM}$ Tris-Cl, $150 \mathrm{mM} \mathrm{NaCl}, 0.1 \%$ $(w / v)$ sodium dodecyl sulfate (SDS) and $0.1 \%(v / v)$ Triton-X$100, \mathrm{pH} 8$ ] with mammalian protease inhibitor cocktail (SigmaAldrich, USA) and subjected to sonication at $10 \AA$ for $15 \mathrm{~s}$ with a pulse of $5 \mathrm{~s}$ each. Then, it was centrifuged at $16,000 \times \mathrm{g}$ for $30 \mathrm{~min}$ at $4^{\circ} \mathrm{C}$. The supernatant thus obtained was the whole-cell lysate. 
In addition, the invasion was also checked by colony-forming unit counting for all the experiments.

\section{For Transfections}

After $24 \mathrm{~h}$ of transfection in HEK 293 cells (as described previously), cells were washed twice with PBS and were harvested by centrifugation at $2,000 \times g$ for $5 \mathrm{~min}$. The pellet was then resuspended in 150-200 $\mu$ l of whole-cell lysis buffer supplemented with mammalian protease inhibitor cocktail. This was then subjected to sonication at $10 \AA$ for $15 \mathrm{~s}$ with a pulse of $5 \mathrm{~s}$ each. Then, it was centrifuged at $16,000 \times g$ for $30 \mathrm{~min}$ at $4^{\circ} \mathrm{C}$, and the supernatant obtained was collected as whole-cell lysate.

\section{Nuclear Lysate Preparation}

Cells $\left(4.5 \times 10^{6}\right)\left(\right.$ three wells of $\left.1.5 \times 10^{6} / \mathrm{ml}\right)$ of RAW 264.7 were plated in a six-well plate overnight for each sample and then infected with wt, $\Delta s t e A$, or compl for $30 \mathrm{~min}$. Then, the bacteria were removed, and RPMI 1640 media containing $100 \mu \mathrm{g} / \mathrm{ml}$ of gentamicin were added to each well for $30 \mathrm{~min}$. Cells were then washed twice with sterile PBS and were then harvested at $2,000 \times g$ for $5 \mathrm{~min}$. The pellet volume was measured, and it was dissolved in five times the pellet volume in hypotonic buffer (10 mM HEPES pH 7.9 with $1.5 \mathrm{mM} \mathrm{MgCl}_{2}$ and $10 \mathrm{mM} \mathrm{KCl}$ ) and centrifuged at $1,850 \times g$ for $5 \mathrm{~min}$ at $4^{\circ} \mathrm{C}$. Then, the pellet was dissolved in hypotonic buffer with $0.5 \mathrm{M}$ dithiothreitol and mammalian protease inhibitor and was then incubated on ice for $15 \mathrm{~min}$. This was then sonicated at $10 \AA$ for $15 \mathrm{~s}$ with three pulses of $5 \mathrm{~s}$ each and centrifuged at $3,300 \times \mathrm{g}$ for $15 \mathrm{~min}$ at $4^{\circ} \mathrm{C}$. The pellet was then resuspended in $70 \mu \mathrm{l}$ of low salt buffer [20 mM HEPES pH 7.9, $1.5 \mathrm{mM} \mathrm{MgCl}_{2}, 20 \mathrm{mM} \mathrm{KCl}, 0.2 \mathrm{mM}$ EDTA, and 25\% $(v / v)$ glycerol] with $0.5 \mathrm{M}$ DTT and mammalian protease inhibitor. To this, $30 \mu \mathrm{l}$ of high salt buffer $[20 \mathrm{mM}$ HEPES pH 7.9, $1.5 \mathrm{mM} \mathrm{MgCl}_{2}, 800 \mathrm{mM} \mathrm{KCl}, 0.2 \mathrm{mM}$ EDTA, and $25 \%(v / v)$ glycerol] was added dropwise and incubated on ice for $10 \mathrm{~min}$ before subjecting to sonication at $10 \AA$ for $15 \mathrm{~s}$. Then, it was incubated on ice for $30 \mathrm{~min}$ with periodic shaking and centrifuged at $24,000 \times g$ for $30 \mathrm{~min}$ at $4^{\circ} \mathrm{C}$. The supernatant hence obtained contained the nuclear lysate.

\section{Immunoblotting}

The whole-cell lysates or the nuclear lysates were run on SDSpolyacrylamide gel electrophoresis (SDS-PAGE) gel and were transferred to polyvinylidene difluoride membrane using wet transfer. After the transfer, the membrane was incubated with 5\% $(w / v)$ bovine serum albumin (BSA) in TBST [20 mM Tris buffer $\mathrm{pH} 7.5,150 \mathrm{mM} \mathrm{NaCl}$, and $0.1 \%(v / v)$ Tween 20] for blocking. Then, it was incubated with various antibodies purchased from different companies. The antibodies against IКB, glyceraldehyde 3-phosphate dehydrogenase (GAPDH), p65, c-Rel, and Lamin B1 were purchased from Santa Cruz Biotechnologies, USA. The antibodies against p-p38, p38, phosphorylated c-Jun N-terminal kinase (p-JNK), JNK, IкB kinase $\alpha / \beta$ (IKK $\alpha / \beta)$, Cullin-1, Cand$1, \beta$-TrCP, Skp-1 and Rbx-1 were purchased from Cell Signaling Technologies, USA. The antibodies against His-tag, HA-tag, and proliferating cell nuclear antigen (PCNA) were purchased from Biolegend, USA. The antibody against Nedd8-Cullin was purchased from Abcam, UK. The antibody against LAMP-1 was purchased from Thermo Fisher Scientific, USA.

The horseradish-peroxidase-tagged secondary antibodies and antibody against glutathione-S-transferase (GST) were purchased from Sigma-Aldrich, USA. The immunoblots were developed using Clarity ${ }^{\mathrm{TM}}$ ECL Substrate (Bio-Rad, USA) and detected using LAS 4000 (GE Healthcare Technologies, USA).

\section{Densitometric Analysis}

The densitometric analysis of the immunoblots was carried out using the Image $\mathrm{J}$ software. The band intensities of I $\mathrm{B}$, $\mathrm{IKK} \alpha / \beta$, p65, or $\mathrm{c}$-Rel were normalized to the respective band intensities of the loading controls, i.e., glyceraldehyde 3phosphate dehydrogenase for whole-cell lysates and PCNA for nuclear lysates. The band intensities of phosphorylated p38 and JNK were normalized to the band intensities of the total p38 and JNK. The lane intensities of ubiquitination and the band intensities of Cand-1 were normalized to the band intensities of $\mathrm{I} \kappa \mathrm{B}$, and the band intensities of neddylated Cullin was normalized to the band intensities of Cullin-1.

\section{Coimmunoprecipitation Studies}

Whole-cell lysates were prepared (as previously described) and were incubated with 1-2 $\mu \mathrm{g}$ of anti-HA, anti-His, anti-Cullin1 , or anti-ІКB antibody for 3-4h with continuous low-speed shaking at $4^{\circ} \mathrm{C}$. Then, $20 \mu \mathrm{l}$ of Protein A/G beads (Santa Cruz Biotechnologies, USA) was added, and it was subjected to continuous low-speed shaking at $4^{\circ} \mathrm{C}$ for overnight. Then, the beads were washed thrice with whole-cell lysis buffer by centrifugation at $6,000 \times g$ for $5 \mathrm{~min}$ at $4^{\circ} \mathrm{C}$. The beads were resuspended in SDS-loading buffer and boiled for $10 \mathrm{~min}$. The samples were then run on SDS-PAGE gel and subjected to immunoblotting.

\section{For IkB Pulldown}

HEK 293 cells were transfected with $3 \mu \mathrm{g}$ of pcDNA3.1(+) or pcDNA3.1(+)steA (as described previously). After $24 \mathrm{~h}$ of transfection, cells were treated with $20 \mathrm{nM}$ of proteasomal inhibitor, MG132 (Sigma-Aldrich, USA), for $3 \mathrm{~h}$. The cells were then stimulated with $10 \mathrm{ng} / \mathrm{ml}$ of $\mathrm{TNF} \alpha$ for $20 \mathrm{~min}$, and wholecell lysates were prepared. The whole-cell lysates were then subjected to coimmunoprecipitation with $2 \mu \mathrm{g}$ of the anti-IкB antibody as described above.

\section{GST Pulldown Assay}

The steA gene was cloned in the plasmid pGEX4T3 (Table 2) using restriction cloning. The empty pGEX4T3 and pGEX4T3steA were each transformed to Escherichia coli Origami B1 cells (Merck, Germany) by chemical transformation method. Then, using these transformants, GST and GSTtagged SteA were overexpressed using $0.1 \mathrm{mM}$ isopropyl $\beta$-D-1-thiogalactopyranoside at $18^{\circ} \mathrm{C}$ for $24 \mathrm{~h}$. The bacteria were pelleted at $2,050 \times g$ for $30 \mathrm{~min}$ at $4^{\circ} \mathrm{C}$. The pellet was resuspended in PBS containing bacterial protease inhibitor cocktail (SigmaAldrich, USA) and was subjected to sonication at $25 \AA$ for $15 \mathrm{~min}$. Then, this was centrifuged at $18,500 \times \mathrm{g}$ for $50 \mathrm{~min}$ at $4^{\circ} \mathrm{C}$ and analyzed by SDS-PAGE. Both GST and GST-tagged SteA 
were found to be present in the soluble fractions. Parallelly, the glutathione beads (Qiagen, USA) were washed twice with lysis buffer [ $50 \mathrm{mM}$ Tris-Cl, $150 \mathrm{mM} \mathrm{NaCl}, 0.05 \%$ ( $v / v)$ NP-40, $\mathrm{pH}$ 7.5]. Then, to $10 \mathrm{ml}$ of the soluble fraction containing GST or GST-tagged SteA, $300 \mu$ l of washed glutathione beads were added and incubated at $4^{\circ} \mathrm{C}$ with shaking. After $2 \mathrm{~h}$ of incubation, the beads were pelleted at $1,800 \times g$ for $5 \mathrm{~min}$ and washed four times with lysis buffer. Then, the beads were incubated with $500 \mu \mathrm{l}$ of $5 \%(w / v)$ BSA in PBS for $90 \mathrm{~min}$. Then, the beads were pelleted and washed four times with lysis buffer. To this, whole-cell lysate of unstimulated RAW 264.7 cells was added and incubated at $4^{\circ} \mathrm{C}$ for $3-4 \mathrm{~h}$ with shaking. Then, the beads were pelleted and washed four times with lysis buffer and resuspended in $40 \mu \mathrm{l}$ of SDS-loading buffer. This was then boiled for $5 \mathrm{~min}$ and subjected to SDS-PAGE and immunoblotting.

\section{Yeast Two-Hybrid Assay}

The coding sequences of IкB, Skp-1, Rbx-1, and Cullin-1 from Mus musculus were taken from www.ncbi.nlm.gov.in. A cDNA library was prepared according to manufacturer's protocol (Invitrogen, Life Technologies, USA) using RNA isolated (according to the manufacturer's protocol; Genetix, India) from untreated RAW 264.7 cells. IкB, Skp-1, and Rbx-1 were amplified from the cDNA library and cloned in pGADC1 (Table 2) plasmid by restriction cloning. Cullin-1 was amplified and cloned in pGADT7 (Table 2) by gateway cloning method according to manufacturer's protocol (Thermo-Fisher, USA). The steA gene was amplified from the Salmonella Typhimurium genome and cloned in $\mathrm{pGBDC1}$ plasmid (Table 2) by restriction cloning. The cloned $\mathrm{AD}$ and the $\mathrm{BD}$ plasmids were cotransformed in yeast (PJ697a) and plated on synthetic complete media deficient in leucine and uracil (SC-Leu, SC-Ura). The colonies thus obtained were then spotted on plates with media deficient in leucine, uracil, and histidine (SC-Leu, SC-Ura, SC-His).

\section{Statistical Analysis}

Data were expressed as mean \pm standard error of mean (SEM), and $p$ values were calculated using Student's two-sided $t$ test or by one-way ANOVA followed by Tukey's multiple comparisons test. Significance is indicated as follows: ${ }^{*} p<0.05,{ }^{* *} p<0.01,{ }^{* * *} p<$ 0.001 , and nonsignificant (ns) when $p>0.05$.

\section{RESULTS}

\section{SteA Affects the Pathogenesis of Salmonella Typhimurium}

To understand the effect of SteA deletion in mouse model of Salmonella infection, we constructed steA deletion mutant $(\triangle$ steA) of Salmonella Typhimurium and steA-complemented strain (compl) with steA-containing plasmid on $\Delta$ steA background. Furthermore, we infected Balb/c mice with $5 \times 10^{5}$ and $5 \times 10^{7}$ wt, $\Delta$ steA, and compl Salmonella Typhimurium. We have observed that the mice infected with $\Delta$ steA died earlier than the wt and compl-infected mice (Figures 1A, B). Furthermore, we have observed that $\Delta s t e A$-infected mice showed symptoms, namely, pilorected fur, decrease in activity, decrease in response to stimulus, and the extent of closing of the eyes that were graded on a scale of 1-4 (34) higher as compared to the control mice (Figure 1C). The scoring indicated that the mice infected with the $\Delta$ steA strain probably died of a heightened immune response. We also checked the body temperatures of mice infected with $5 \times 10^{5}$ wt, $\triangle$ steA, and compl and found lower body temperatures of $\triangle$ steAinfected mice, indicating that probably mice were undergoing sepsis (35).

Furthermore, to probe whether there was any increase in the proinflammatory cytokine levels in $\Delta$ ste $A$-infected mice compared to the controls, we checked TNF $\alpha$, IL-6, IL- $1 \beta$, IFN- $\gamma$, IL-12, and IL-10 in the serum of the infected mice and found higher TNF $\alpha$, IL-6, IFN- $\gamma$, IL-12, and IL-10 level in the serum of the $\Delta$ steA-infected compared to wt- or compl-infected mice (Figure S1). Furthermore, we have isolated mononuclear cells from the spleen of mice infected with wt, $\Delta$ steA, and compl strains and analyzed the expression of TNF $\alpha$ and IL- 6 genes. We have observed higher expression of both TNF $\alpha$ and IL-6 genes in cells isolated from mice infected with the $\Delta$ ste $A$ strains as compared to the wt- and compl-infected mice (Figure 1E). Therefore, in accordance with our hypothesis, it seemed that there was an elevated inflammatory immune response in $\Delta s t e A$-infected mice compared to the controls. Furthermore, to check if the difference in immune response was due to a difference in the colonization pattern of $\Delta$ ste $A$ compared to the wt strain, we have isolated spleen and enumerated the bacteria by colony-forming unit counting. No difference in the colonization of Salmonella Typhimurium was observed in the spleen of these respective strain-infected mice (Figure 1F). Altogether, these results suggested that during Salmonella Typhimurium infection, absence of SteA enhances the host-inflammatory responses.

\section{Increased TNF $\alpha$ Production in Macrophages Infected With $\Delta s t e A$}

To further confirm that there is heightened inflammatory response upon infection with $\Delta$ steA, we infected RAW 264.7 (murine macrophage cell line) and BMDMs with wt, $\Delta$ steA, and compl strains. After $8 \mathrm{~h}$ of infection, supernatants were collected and analyzed for TNF $\alpha$. In both the cell types, a higher TNF $\alpha$ production was observed when infected with $\triangle$ steA compared to the wt and the compl-infected cells (Figure 2A). We further checked the cell cytotoxicity upon infection with wt, $\Delta s t e A$, and compl strains to probe whether this difference in $\mathrm{TNF} \alpha$ production was due to a difference in cell death. However, we did not find any difference in cell cytotoxicity in RAW 264.7 or BMDMs infected with wt, $\Delta s t e A$ or compl (Figure S2). Therefore, our data confirmed that the Salmonella Typhimurium-mediated host-immune responses increase in the absence of SteA.

SteA is secreted by both T3SS-1 and T3SS-2. In addition, recently, it was reported that SteA could be secreted by T3SS2 as early as $15 \mathrm{~min}$ in RAW 264.7 cells (24). Therefore, we wanted to check whether the observed effect of SteA was due to T3SS-2 effector function. To address this, we have used a $\Delta$ spi2 mutant of Salmonella Typhimurium and a $\Delta$ steA mutant 
A

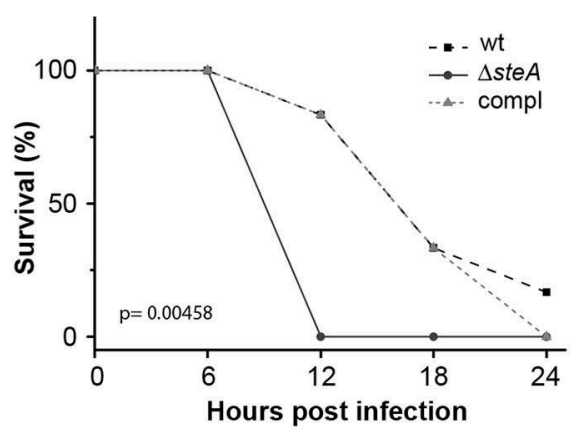

C

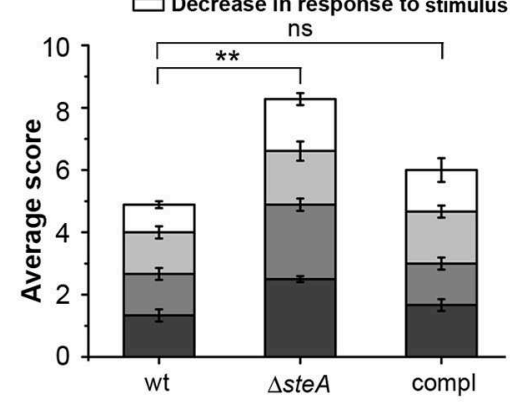

B
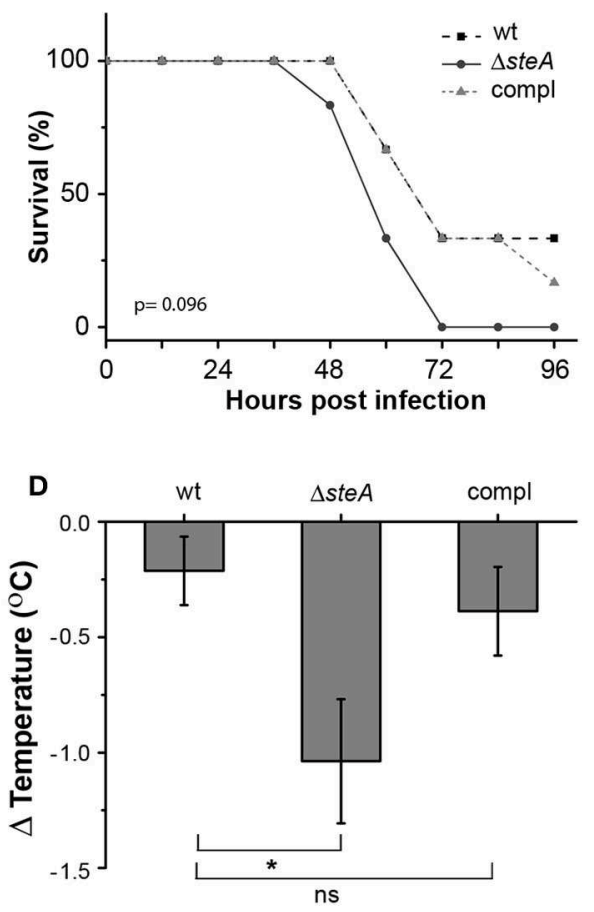

E

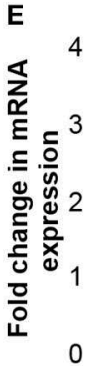

E

TNF $\alpha$

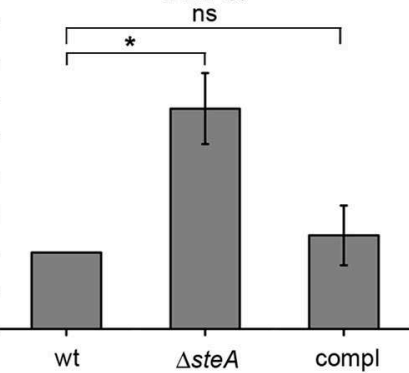

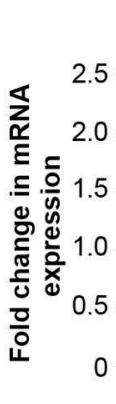

IL-6

ns

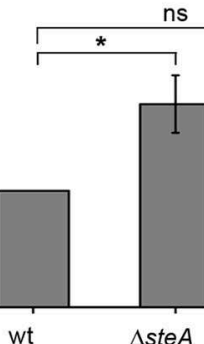

n

F

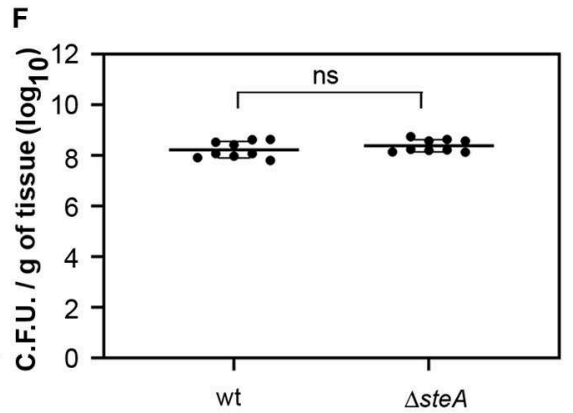

FIGURE 1 | $\triangle$ steA-infected mice had lower survival and higher immune responses than the wt or compl. (A,B) Balb/c mice infected with the steA deletion mutant $(\Delta s t e A)$ had lower survival than those infected with wild type (wt) and the steA-complemented (compl) strain of Salmonella Typhimurium. Balb/c mice 6-8 weeks old were infected intraperitoneally with $5 \times 10^{7}$ bacteria and monitored over a period of $24 \mathrm{~h}$ (A) or with $5 \times 10^{5}$ bacteria and monitored over a period of $96 \mathrm{~h}$ (B). After every $6 \mathrm{~h}(\mathbf{A})$ or $12 \mathrm{~h}$ (B), the percentage of survival was calculated as (the number of mice surviving/total mice infected) $\times 100$. The graph represents the percentage of survival of mice infected with wt, $\Delta$ steA, or compl strains with six mice in each group. $p$ values were calculated using Kaplan-Meir survival test. (C) Balb/c mice infected with $\triangle$ steA showed advanced symptoms of a heightened immune response as compared to the wt and the compl-infected mice. Balb/c mice 6-8 weeks old were infected intraperitoneally with $5 \times 10^{5}$ bacteria and scored for symptoms, namely, decrease in activity, decrease in response to stimuli, extent of closing of the eye, and the extent of pilorected fur at $36 \mathrm{~h}$ postinfection (hpi). For each experiment, the average of total scores for three or four mice infected with either wt, $\Delta s t e A$, or compl was calculated. Bar graph represents mean \pm SEM from three independent experiments. $p$ values were calculated using one-way ANOVA of the total scores from three independent experiments $\left({ }^{*} p<0.05,{ }^{* \star} p<0.01,{ }^{* \star *} p<0.001\right.$, ns $p>0.05$ vs. wt-infected mice). (D) Body temperatures of Balb/c mice infected with $\Delta$ steA were lower than wt- or compl-infected mice. Balb/c mice 6-8 weeks old were infected intraperitoneally with $5 \times 10^{5}$ bacteria, and the body temperatures of mice were recorded before infection and at $24 \mathrm{hpi}$. Then, the difference in body temperature was calculated ( $\triangle$ Temperature). Bar graph represents mean $\pm \mathrm{SEM}$ from eight mice in each group. $p$ values were calculated using one-way ANOVA of $\Delta$ Temperature of eight mice from each group $(n=8)\left({ }^{*} p<0.05\right.$, ${ }^{* \star} p<0.01$, ${ }^{* \star \star} p<$ 0.001 , ns $p>0.05$ vs. wt-infected mice). (E) Tumor necrosis factor alpha (TNF $\alpha$ ) and interleukin (IL)-6 gene expression was higher in mononuclear cells isolated from spleen of mice infected with $\triangle$ steA compared to those infected with wt or compl. The spleens of Balb/c mice infected with $5 \times 10^{5}$ bacteria were isolated at 36 hpi. The mononuclear cells were isolated using density-dependent separation [with bovine serum albumin (BSA)]. RNA was isolated from these cells; then, complementary DNA (CDNA) was prepared and gene expression of TNF $\alpha$ and IL-6 was analyzed by semiquantitative PCR. Fold change in gene expressions was calculated with respect to the gene expression in cells from mice infected with wt. Bar graph represents mean \pm SEM from three independent experiments. $p$ values were calculated using one-way ANOVA $\left({ }^{*} p<0.05,{ }^{* *} p<0.01,{ }^{* \star *} p<0.001\right.$, ns $p>0.05$ vs. wt-infected mice). (F) No significant difference in the colonization of wt and $\Delta s t e A$ Salmonella Typhimurium in spleen of infected mice. Bacteria were enumerated in spleen of Balb/c mice infected intraperitoneally with $5 \times 10^{5}$ bacteria at 36 hpi. Graph represents colony-forming units (CFU) enumerated per milligram of spleen tissue from nine mice each (represented as a dot $\bullet$ ). $p$ values were calculated using Student's $t$ test $\left({ }^{\star} p<0.05,{ }^{\star \star} p<0.01,{ }^{\star \star *} p<0.001\right.$, ns $p>0.05$ vs. wt-infected mice). 

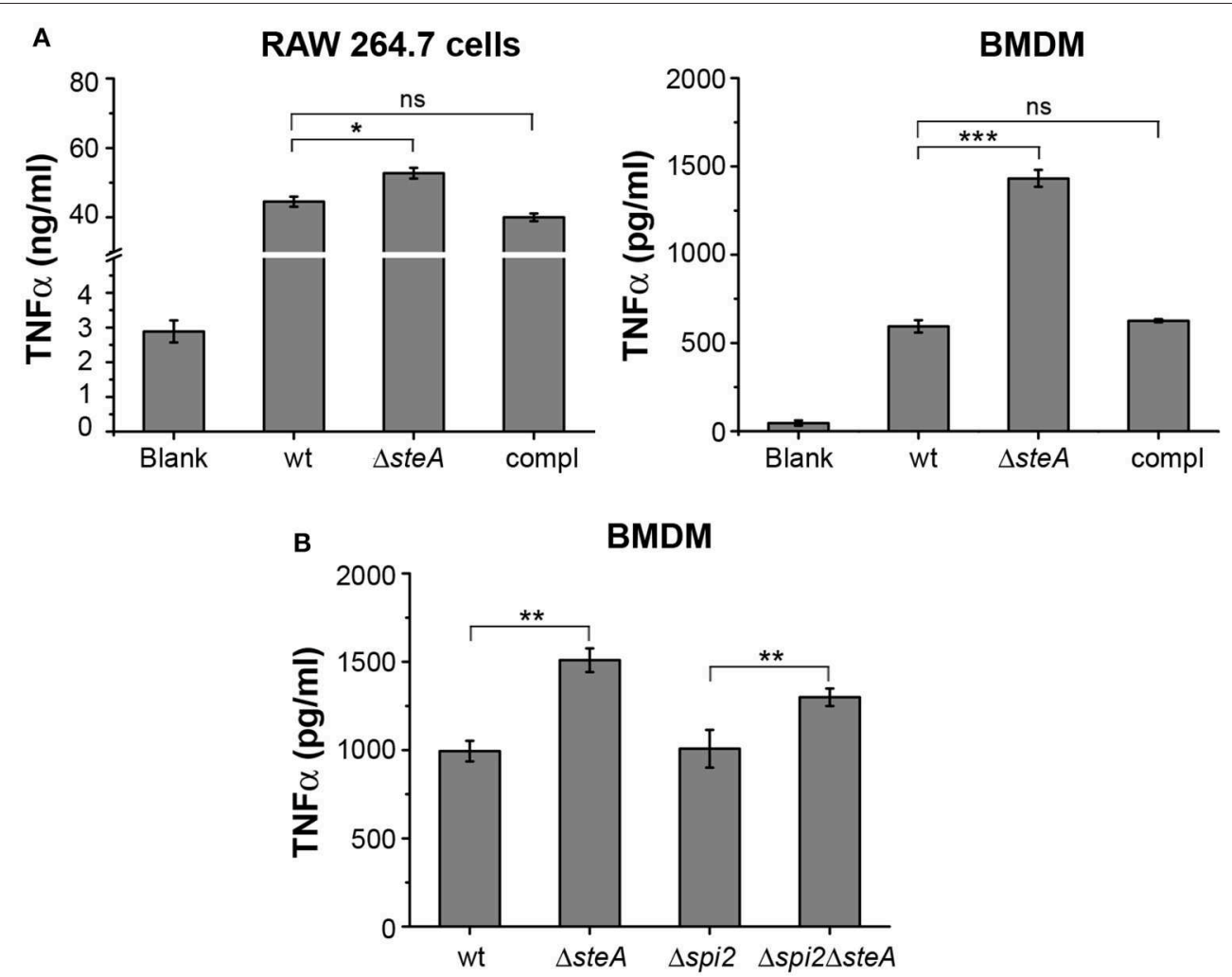

FIGURE 2 | SteA suppresses proinflammatory responses in macrophages during Salmonella Typhimurium infection. (A) Tumor necrosis factor alpha (TNF $\alpha$ ) production was higher in RAW 264.7 macrophages and bone-marrow-derived macrophages (BMDMs) infected with $\triangle$ steA as compared to the controls. RAW 264.7 cells and BMDMs were infected with wt, $\triangle$ steA, or the compl [at an multiplicity of infection (MOI) of 20:1 for RAW 264.7 and 10:1 for BMDMs]. The supernatant was collected after $8 \mathrm{~h}$ of infection and analyzed for TNF $\alpha$ by ELISA. Bar graph represents mean \pm SEM from three independent experiments. $p$ values were calculated using one-way ANOVA ( ${ }^{*} p<0.05,{ }^{* *} p<0.01,{ }^{* *} p<0.001$, ns $p>0.05$ vs. wt-infected cells). (B) SteA-mediated immune suppression is not affected by the absence of spi2 gene cluster ( $\Delta$ spi2), indicating that this effect of SteA is not SPI-2 dependent. BMDMs were infected at an MOI of $10: 1$ with wt, $\Delta$ steA, $\Delta$ spi2, and $\Delta$ spi2 $\Delta$ steA. Supernatant was collected after $8 \mathrm{~h}$, and TNF $\alpha$ was quantified by ELISA. Bar graph represents mean \pm SEM from three independent experiments. $p$ values were calculated using Student's $t$ test $\left({ }^{\star} p<0.05,{ }^{\star \star} p<0.01,{ }^{\star \star *} p<0.001\right.$, ns $p>0.05$ vs. wt or $\Delta$ spi2-infected cells).

in $\Delta$ spi2 background ( $\Delta$ spi2 $\Delta$ steA). We have treated BMDMs with wt, $\Delta$ steA, $\Delta$ spi2, and $\Delta$ spi2 $\Delta$ steA strains. After $8 \mathrm{~h}$, we collected the supernatants and analyzed for TNF $\alpha$ by ELISA. The cells infected with $\Delta s p i 2 \Delta s t e A$ showed higher TNFa production than $\Delta$ spi2-infected cells in BMDMs (Figure 2B), indicating that SteA-mediated effect on the immune response is not T3SS2 dependent.

\section{SteA Acts on the NF-кB Pathway to Suppress the Immune Responses}

An immune response involves the activation of majorly two transcription factors NF- $\kappa$ B and AP-1. The phosphorylation of mitogen-activated protein (MAP) kinases p38 and/or JNK majorly leads to the activation of AP-1 (36). To check whether MAP kinases could be involved in $\triangle$ steAmediated heightened immune response, we infected RAW 264.7 cells with wt, $\Delta s t e A$, and compl strains and checked whether there is an increase in the phosphorylation levels of p38 and JNK MAP kinases in the whole-cell lysates. No difference in the phosphorylation level of p38 and JNK was observed in any of the treatments (Figures 3A,B). As phosphorylation levels are indicative of activation levels, our study indicated that SteA probably does not interfere in the MAP kinase activation pathway. As activation of the AP-1 transcription factor is dependent on MAP kinase activation, we presumed that probably SteA-mediated effect is not via the AP-1 pathway.

Furthermore, we wanted to check whether SteA has any effect on the activation of NF- $\kappa \mathrm{B}$. In an inactivated state, NF$\kappa \mathrm{B}$ remains bound to its inhibitor $\mathrm{I} \kappa \mathrm{B}$, which prevents the translocation of NF- $\mathrm{B}$ to the nucleus. Upon phosphorylation of $\mathrm{I} \kappa \mathrm{B}$ by upstream kinase $\mathrm{I} K K \alpha / \beta$, I $\kappa \mathrm{B}$ gets ubiquitinated and degraded through proteasome rendering NF- $\kappa \mathrm{B}$ free to translocate to the nucleus $(31,37)$. We observed that in $\triangle$ steAinfected RAW 264.7 cells and BMDMs, there is increased IкB degradation compared to control infected cells (Figures 4A, B). NF-кB is known to be activated in HEK 293 cells in response to TNF $\alpha$. To confirm the observation that SteA affects the degradation of $\mathrm{I} \kappa \mathrm{B}$, we endogenously expressed SteA in HEK 293 cells and probed the IкB levels upon stimulation 
A
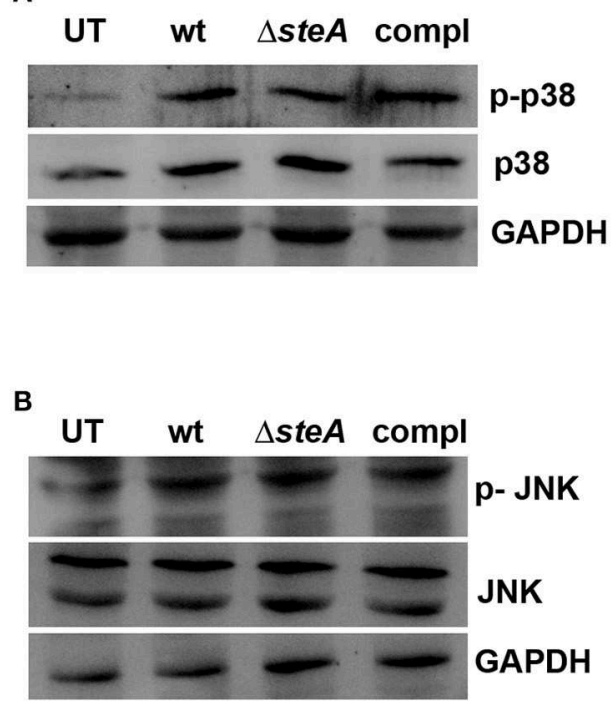
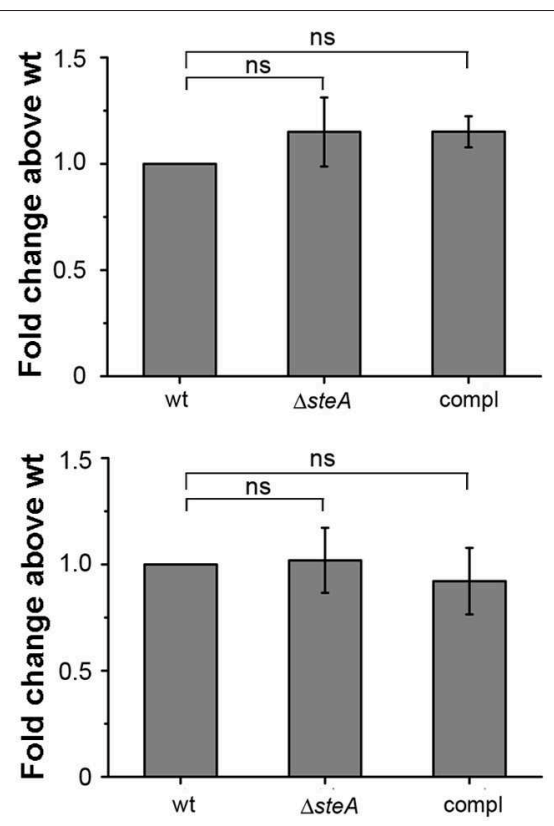

FIGURE 3 | SteA does not affect the mitogen-activated protein (MAP)-kinase activation. (A,B) The phosphorylation levels of the MAP kinases p38 (A) and c-Jun $\mathrm{N}$-terminal kinase (JNK) (B) remained unchanged upon infection with $\triangle$ steA as compared to the controls. RAW 264.7 cells were infected with wt, $\triangle$ steA, or compl strains at an multiplicity of infection (MOI) of 20:1, and whole-cell lysates were prepared after 30 min of infection. Whole-cell lysates were probed for phosphorylated levels of p38 and JNK by Western blots and densitometric analysis along with total p38 and JNK levels. Glyceraldehyde 3-phosphate dehydrogenase (GAPDH) was used as a loading control. For densitometric analysis, fold change was calculated with respect to wt. Bar graphs represent mean \pm SEM from three independent experiments. $p$ values were calculated using one-way ANOVA $\left({ }^{\star} p<0.05\right.$, ${ }^{\star \star} p<0.01,{ }^{\star \star \star} p<0.001$, ns $p>0.05$ vs. wt-infected cells). UT stands for untreated cells.

with $\mathrm{TNF} \alpha$. We observed increased I $\mathrm{B}$ degradation in $\mathrm{TNF} \alpha$ activated cells transfected with the empty plasmid, but in cells expressing SteA, IкB degradation was found to be inhibited (Figure 4C). Furthermore, we also observed less ІкB in splenic lysates of mice infected with $\triangle$ ste $A$ compared to the control (Figure 4D).

More degradation of I $\mathrm{B}$ suggests increased translocation of $\mathrm{NF}-\kappa \mathrm{B}$ to the nucleus. Among the NF- $\kappa \mathrm{B}$ family members, p65 and/or c-Rel are involved in the transcription of proinflammatory genes (37). Thus, to probe if IкB degradation corresponds to the nuclear translocation of NF- $\kappa \mathrm{B}$, we infected RAW 264.7 cells with wt, $\Delta$ steA, and compl strains and checked the levels of p65 and c-Rel in the nuclear lysates. We observed that the nuclear translocation of both p65 and c-Rel were more in cells infected with $\triangle$ steA compared to the wt and the compl-infected cells (Figure 5A). This observation indicated that the NF- $\kappa \mathrm{B}$ activation during Salmonella Typhimurium infection increases in the absence of SteA. Furthermore, to confirm that SteA suppresses NF- $\kappa$ B activation, we transfected HEK 293 and RAW 264.7 cells with NF- $\mathrm{B}$ promoter-reporter plasmid and then infected with wt, $\Delta$ ste $A$, and compl strains. The cells infected with $\Delta s t e A$ showed higher NF- $\mathrm{B}$ reporter activity than wt and the compl strains in both HEK 293 and RAW 264.7 cells (Figure 5B). Furthermore, we wanted to know if endogenous expression of SteA could also suppress NF- $\kappa$ B activation. Toward this, we endogenously expressed SteA in HEK 293 cells and then transfected with the NF- $\mathrm{B}$ promoter-reporter plasmid. We observed that upon stimulation with $\mathrm{TNF} \alpha$, there is diminished NF- $\kappa$ B reporter activity in endogenous SteA-expressing cells as compared to the cells transfected with empty plasmid (Figure 5C).

Altogether, these results confirm that SteA suppresses the immune responses by acting on the NF-кB pathway.

\section{SteA Interferes With the IкB Ubiquitination}

I $\mathrm{B}$ phosphorylation by $\mathrm{IKK} \alpha / \beta$ is a prerequisite for $\mathrm{I} \kappa \mathrm{B}$ degradation. In response to an infection, a signaling cascade leads to the phosphorylation of $\mathrm{IKK} \alpha / \beta$, which in turn phosphorylates IкB (36). Since we have observed that there is more IкB degradation in $\Delta$ steA-infected cells compared to the controls (Figure 4), we wanted to check whether this was due to increased activation of $I K K \alpha / \beta$. No change was observed in the phosphorylation levels of IKK $\alpha / \beta$ in both RAW 264.7 macrophages and BMDMs infected with wt, $\Delta$ steA, and compl strains (Figure 6A). This result indicated that increased degradation of I $\kappa$ B is probably not due to increased activation of $\mathrm{IKK} \alpha / \beta$. Hence, SteA seems to act downstream to the activation of IKK $\alpha / \beta$ for suppression of I $\mathrm{B}$ degradation.

The degradation of $\mathrm{I} \kappa \mathrm{B}$ requires its polyubiquitination. To probe if SteA was interfering with the polyubiquitination of I $\mathrm{B}$ and subsequently its degradation, SteA-expressing HEK 293 cells were pretreated with a pharmacological inhibitor (MG132), 
A

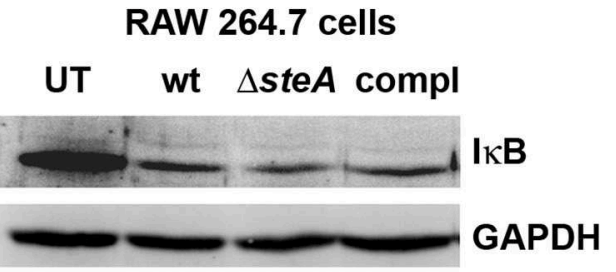

B

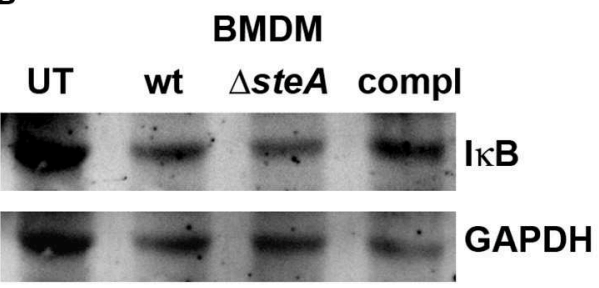

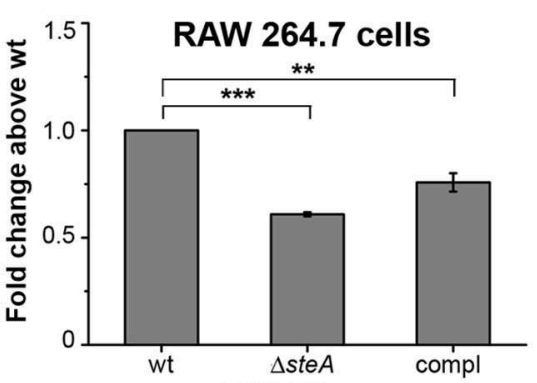

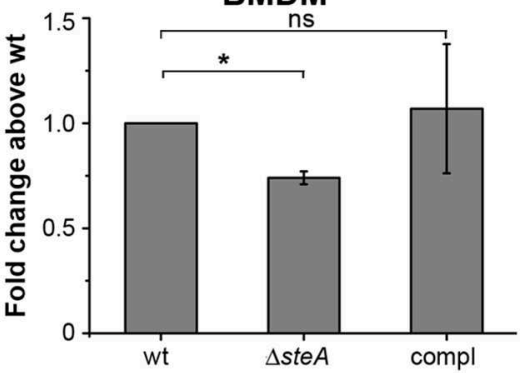

C pcDNA3.1(+) transfected HEK 293 cells
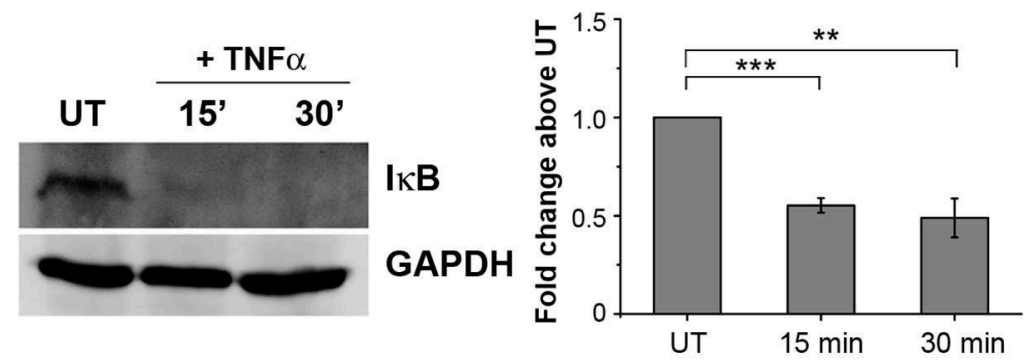

pcDNA3.1(+)steA transfected HEK 293 cells
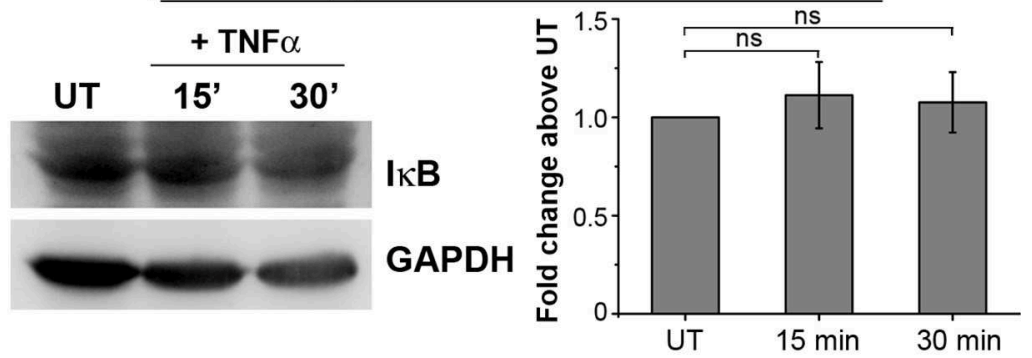

D

wt $\Delta$ steA compl
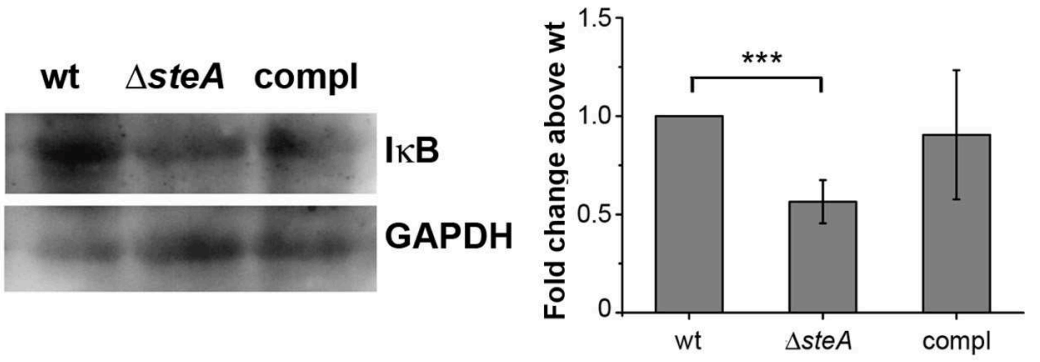

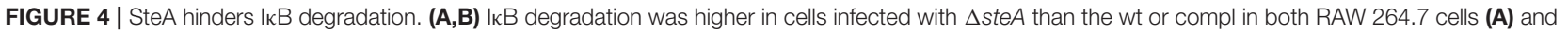
bone-marrow-derived macrophages (BMDMs) (B) as shown by Western blot and densitometric analysis. RAW 264.7 cells and BMDMs were infected with wt, $\triangle$ steA, or compl at an multiplicity of infection (MOI) of 20:1 and 10:1, respectively, and whole-cell lysates were prepared after 30 min of infection. The levels of IкB were probed by Western blotting. (A,B) Glyceraldehyde 3-phosphate dehydrogenase (GAPDH) was used as a loading control in all the experiments. UT stands for untreated cells. 
FIGURE 4 | For densitometric analysis, fold change was calculated with respect to wt. Bar graphs represent mean \pm SEM from three independent experiments. $p$ values were calculated using one-way ANOVA $\left({ }^{*} p<0.05,{ }^{* *} p<0.01,{ }^{* *} p<0.001\right.$, ns $p>0.05$ vs. wt-infected cells). (C) Endogenous expression of SteA suppresses the degradation of $\mathrm{IK}_{\mathrm{K}}$ in HEK 293 cells. HEK 293 cells were transfected with pcDNA3.1(+)steA or pcDNA3.1(+) empty plasmid. After $18 \mathrm{~h}$ of transfection, cells were stimulated with TNF $\alpha$ for 15 and 30 min. Whole-cell lysates were then prepared, and lkB levels were analyzed by Western blotting and densitometry. GAPDH was used as a loading control in all the experiments. UT stands for untreated cells. For densitometric analysis, fold change was calculated with respect to UT cells. Bar graphs represent mean \pm SEM from three independent experiments. $p$ values were calculated using Student's $t$ test $\left({ }^{*} p<0.05,{ }^{* *} p<0.01,{ }^{* * *} p<0.001\right.$, ns $p>0.05$ vs. UT cells). (D) IkB levels were lower in splenic lysates of mice infected with $\Delta s t e A$ as compared to the control-infected mice. Balb/c mice were infected with wt, $\Delta s t e A$, or compl, and spleen was isolated at 36 hpi. Splenic lysates were then prepared, and the levels of $\mathrm{I}_{\mathrm{K}} \mathrm{B}$ were probed by Western blotting and densitometric analysis. GAPDH was used as a loading control in all the experiments. For densitometric analysis, fold change was calculated with respect to wt. Bar graphs represent mean \pm SEM from three independent experiments. $p$ values were calculated using Student's $t$ test $\left({ }^{\star} p<0.05,{ }^{* *} p<0.01,{ }^{* \star *} p<0.001\right.$, ns $p>0.05$ vs. wt-infected mice).
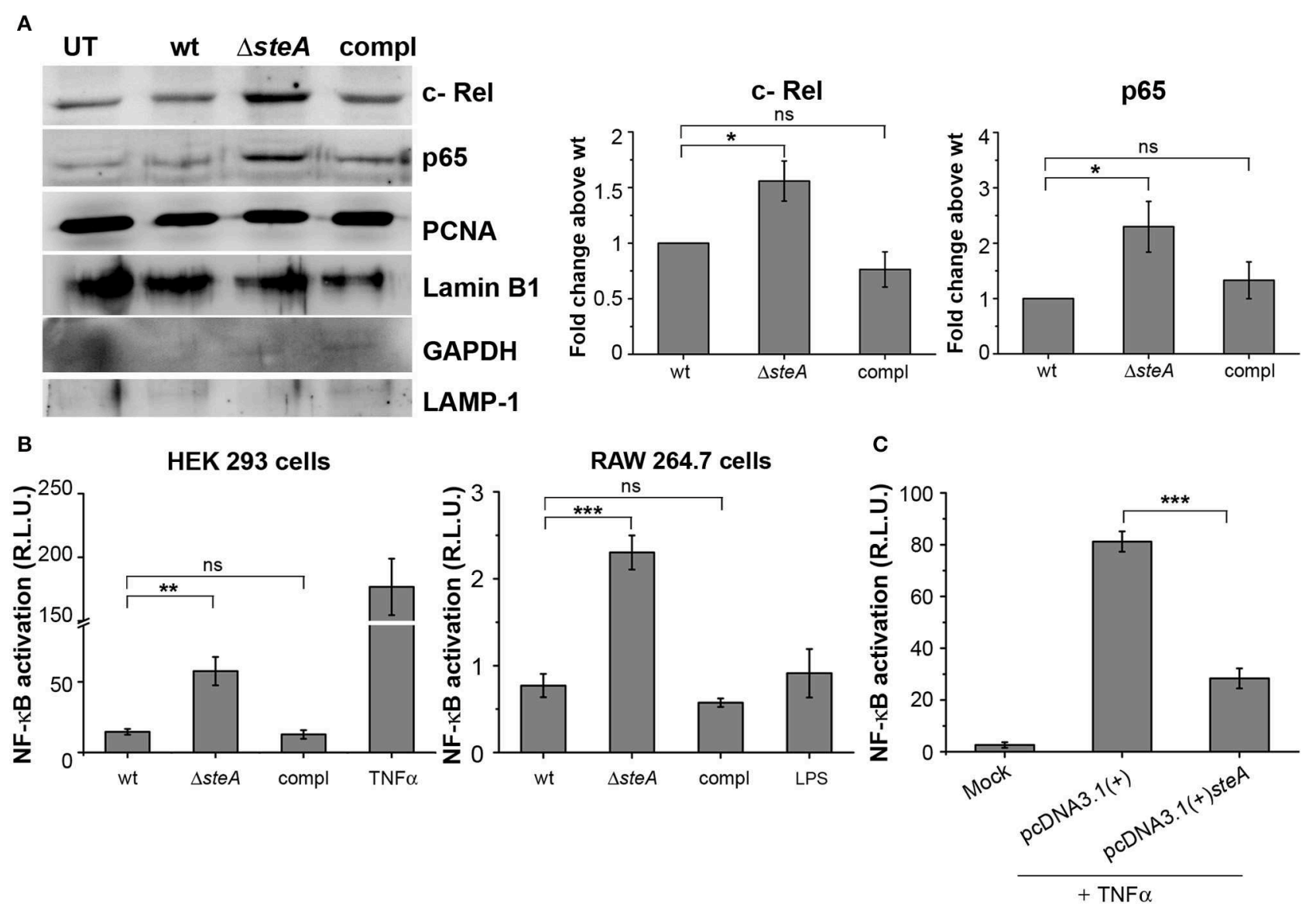

FIGURE 5 | SteA suppresses the nuclear factor kappa B (NF-kB) activation. (A) The translocation of NF-kB subunits (p65 and c-Rel) was more in cells infected with $\Delta s t e A$ than the controls. Nuclear lysates were prepared following infection of RAW 264.7 macrophages with wt, $\Delta s t e A$, or compl for 30 min. p65 and c-Rel were probed by Western blotting and densitometry. Proliferating cell nuclear antigen (PCNA) and Lamin B1 were used as a loading control for nuclear fractions. In addition, GAPDH and LAMP-1 were used as non-nuclear markers to check the purity of the nuclear lysates. For densitometric analysis, fold change was calculated with respect to wt. (B) NF-kB reporter activity was higher upon infection of HEK 293 cells and RAW 264.7 cells with $\Delta$ steA than the wt or the compl-infected cells. HEK 293 or RAW 264.7 cells were transfected with NF-kB luciferase reporter plasmid and pRL (renilla luciferase) plasmid. After 18 or $12 \mathrm{~h}$ of transfection, respectively, cells were infected with wt, $\triangle$ steA, or compl at an multiplicity of infection (MOI) of 20:1 (HEK 293 cells) or 5:1 (RAW 264.7 cells), and the reporter activity was measured following 8 or $15 \mathrm{~h}$ of infection, respectively. Tumor necrosis factor alpha (TNF $\alpha$ ) stimulated HEK 293 cells, and lipopolysaccharide (LPS)-stimulated RAW 264.7 cells were taken as positive control for the experiment. (A,B) Bar graph represents mean $\pm \mathrm{SEM}$ from three independent experiments. $p$ values were calculated using one-way ANOVA ( ${ }^{*} p<0.05,{ }^{* \star} p<0.01,{ }^{* \star *} p<0.001$, ns $p>0.05$ vs. wt-infected cells). (C) Endogenous expression of SteA in HEK 293 cells suppresses the NF-kB reporter activity upon TNF $\alpha$ stimulation. HEK 293 cells were transfected with NF-kB Luciferase reporter plasmid, pRL plasmid, and pcDNA3.1(+)steA or pcDNA3.1(+) empty plasmid. After $18 \mathrm{~h}$ of transfection, cells were stimulated with TNF $\alpha$, and the reporter activity was measured after $8 \mathrm{~h}$. Bar graph represents mean $\pm \mathrm{SEM}$ from three independent experiments. $p$ values were calculated using Student's $t$ test $\left[{ }^{\star} p<0.05,{ }^{* \star} p<0.01,{ }^{\star \star *} p<0.001\right.$, ns $p>0.05$ vs. pcDNA3.1(+) transfected cells]. 
A
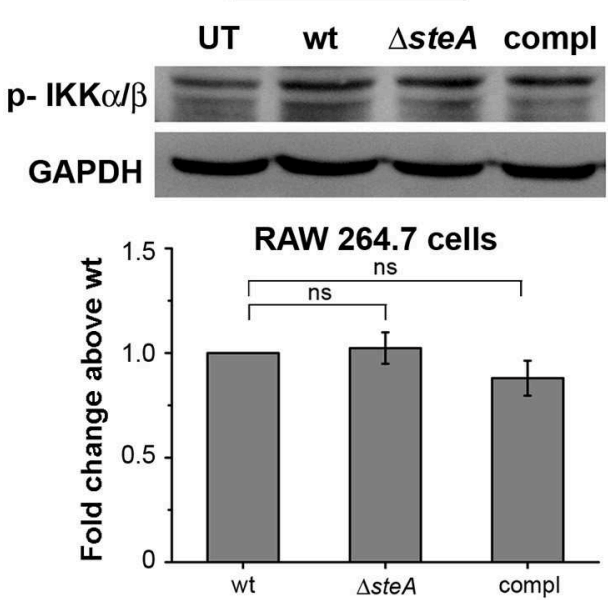

B

B IP: IKB
RAW 264.7 cells

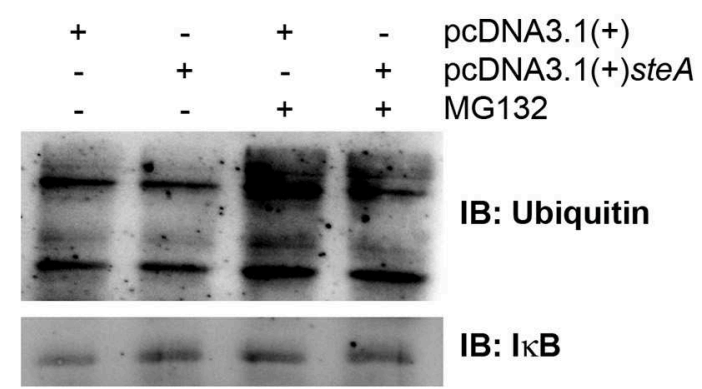

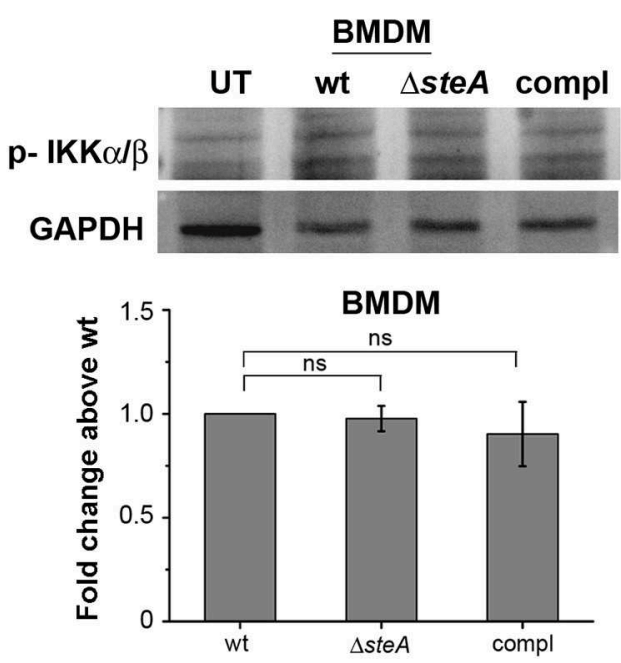

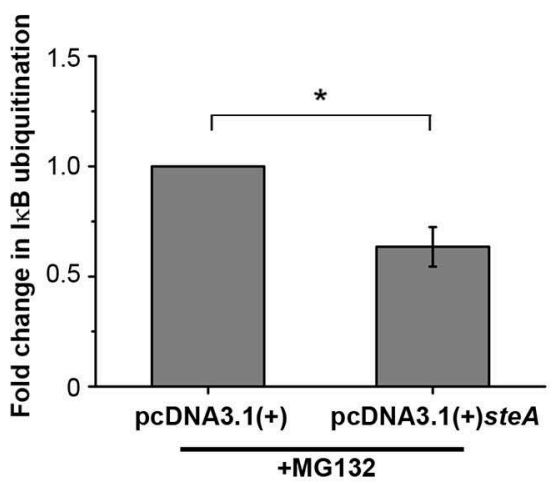

FIGURE 6 | SteA acts on the ubiquitination of $I_{\kappa} B$ but does not affect the activation of upstream kinase (IKK). (A) SteA does not affect the activation of IKK $\alpha / \beta$. RAW 264.7 cells, and BMDMs were infected with wt, $\Delta$ steA, or compl at an $\mathrm{MOI}$ of 20:1 and 10:1, respectively, and whole-cell lysates were prepared following 30 min of infection. The levels of $\mathrm{IKK} \alpha / \beta$ were probed by Western blotting and densitometry. For densitometric analysis, fold change was calculated with respect to wt. Bar graphs represent mean \pm SEM from three independent experiments. $p$ values were calculated using one-way ANOVA $\left({ }^{\star} p<0.05,{ }^{* \star} p<0.01,{ }^{* \star *} p<0.001\right.$, ns $p>$ 0.05 vs. wt-infected cells). (B) SteA suppresses the ubiquitination of IкB. HEK 293 cells were transfected with pcDNA3.1(+)steA or pcDNA3.1(+) empty plasmid. After $24 \mathrm{~h}$ of transfection, cells were pretreated with proteasomal inhibitor MG132 for $3 \mathrm{~h}$ and stimulated with TNF $\alpha$ for 20 min. Whole-cell lysates were then prepared and immunoprecipitated with anti-IкB antibody. Ubiquitination was then analyzed by Western blotting and densitometry. (A,B) Glyceraldehyde 3-phosphate dehydrogenase (GAPDH) was used as a loading control. For densitometric analysis, fold change was calculated with respect to pcDNA3.1(+) transfected cells. Bar graphs represent mean \pm SEM from three independent experiments. $p$ values were calculated using Student's $t$ test $\left[{ }^{*} p<0.05,{ }^{* *} p<0.01,{ }^{* \star *} p<0.001\right.$, ns $p>0.05$ vs. pcDNA3.1 $(+)$ transfected cells].

which prevents the proteasomal degradation of ubiquitinylated proteins and immunoprecipitated with anti-IкB antibody. We observed that the ubiquitination of IКB was less when SteA was present (Figure 6B).

Altogether, these results showed that SteA interferes with the ubiquitination of I $\mathrm{B}$ to suppress the host proinflammatory responses.

\section{SteA Does Not Inhibit the Recruitment of E3 Ligase Components to IKB}

For ubiquitination to happen, the phosphorylated $\mathrm{I} \kappa \mathrm{B}$ is recognized by the Skp-1, Cullin-1, F-box (SCF)-E3 ligase complex. Recruitment of the SCF complex to the phosphorylated IкB happens through F-box protein $\beta$ - $\operatorname{TrCP}(31,38)$. Therefore, to probe whether SteA could affect the recruitment of the
SCF complex to I $\mathrm{B}$, we immunoprecipitated the lysates of wt and $\Delta$ ste $A$-infected RAW 264.7 macrophages with anti- $\beta$-TrCP antibody and observed the association of SCF complex with IкB both in presence or absence of SteA. This showed that SteA was not interfering with the assembly of the SCF-E3 ligase complex to phosphorylated IкB (Figure 7A and Figure S3A).

Furthermore, to understand how SteA affects IкB ubiquitination, we checked whether SteA could associate with IкB. Toward this, we overexpressed SteA in HEK 293 cells and checked the localization of SteA with IКB upon stimulation with $\mathrm{TNF} \alpha$ using confocal microscopy. We observed that IкB and SteA colocalize upon stimulation in cells overexpressing SteA (Figure 7B). Furthermore, to confirm the association of SteA with IкB and SCF complex, we have immunoprecipitated HA-tagged SteA-expressing HEK 293 cell 


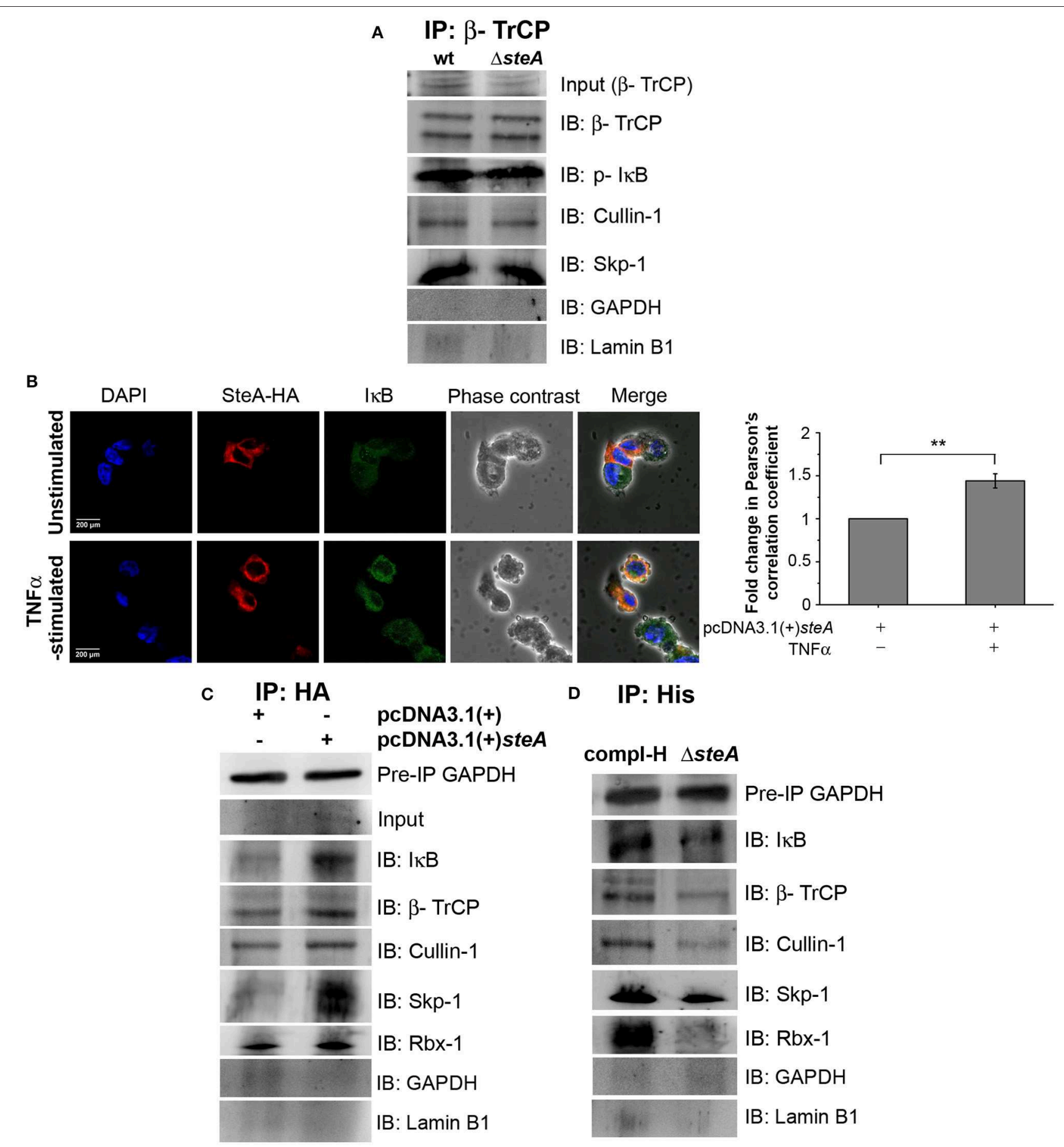

FIGURE 7 | SteA localizes to the SCF-E3 ligase complex. (A) The SCF-E3 ligase complex assembled at phosphorylated IкB ( $p$-IкB) in the presence or absence of SteA. RAW 264.7 cells were infected with wt or $\triangle$ steA strains at an multiplicity of infection (MOI) of 20:1 for 30 min. Whole-cell lysates were then prepared and subjected to immunoprecipitation with anti- $\beta$-TrCP antibody. The Skp-1, Cullin-1, F-box (SCF) complex members and p-IкB were then probed by Western blotting. Glyceraldehyde 3-phosphate dehydrogenase (GAPDH) and Lamin B1 were also probed after IP to check the specificity of the pulldowns. (B) The colocalization of SteA and I $_{\kappa}$ increased upon tumor necrosis factor alpha (TNF $\alpha$ ) stimulation as compared to the unstimulated control as observed under confocal microscopy. HEK 293 cells overexpressing HA-tagged SteA were fixed after 30 min of TNF $\alpha$ stimulation and were incubated with anti-IKB and anti-HA primary antibodies. Then, the cells were stained with Alexa 488-tagged (for $\mathrm{I}_{\kappa} \mathrm{B}$ ), Alexa 568-tagged (for HA) secondary antibodies, and 4',6-diamidino-2-phenylindole (DAPI; for the nucleus). The cells were then observed under a confocal microscope. The colocalization was quantified using Pearson's correlation coefficient (PCC) taking $8-10$ fields per experiment. Bar graph represents as mean \pm SEM from three independent experiments $\left({ }^{\star} p<0.05,{ }^{\star *} p<0.01,{ }^{\star \star \star} p<0.001\right.$, ns $p>0.05$ vs. fold change of PCC in unstimulated cells). (C,D) SteA localizes to the SCF-E3 ligase complex on IкB. (C) HEK 293 cells were transfected with pcDNA3.1(+)steA or pcDNA3.1(+) empty vector. After 18 h 
FIGURE 7 | of transfection, cells were stimulated with TNF $\alpha$ for $30 \mathrm{~min}$, and whole-cell lysates were immunoprecipitated with anti-HA antibody. (D) RAW 264.7 cells were infected with $\triangle$ steA and $\triangle$ steA complemented with His-tagged SteA (compl-H) at an MOI of 20:1 for 30 min. Whole-cell lysates were then prepared and subjected to immunoprecipitation with anti-His antibody. (C,D) SCF complex members and IkB were then probed by Western blotting. GAPDH in the preimmunoprecipitation (pre-IP) samples was used as a loading control for the coimmunoprecipitation. GAPDH and Lamin B1 were also probed after IP to check the specificity of the pulldowns.
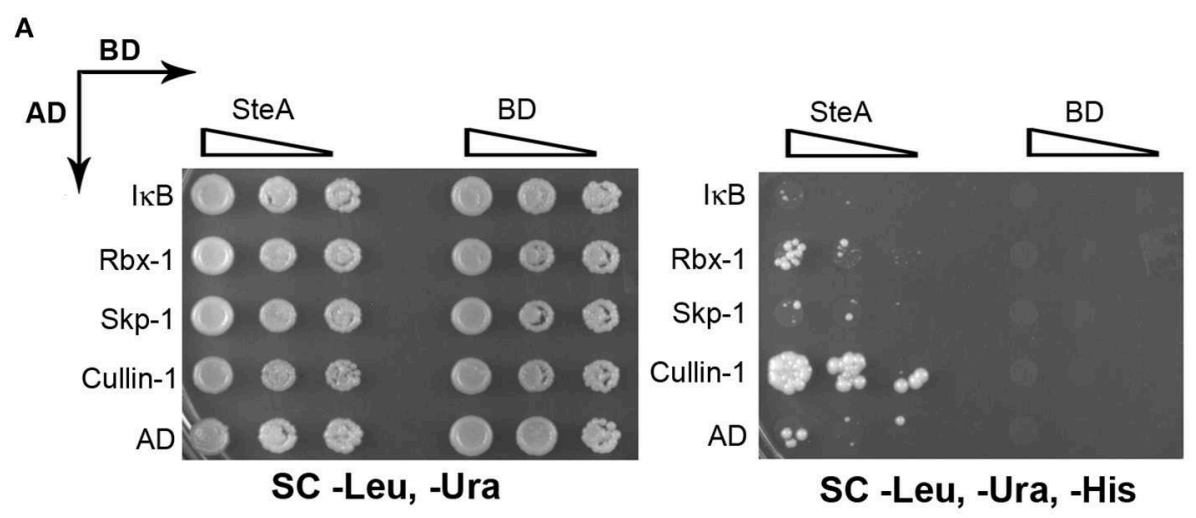

B

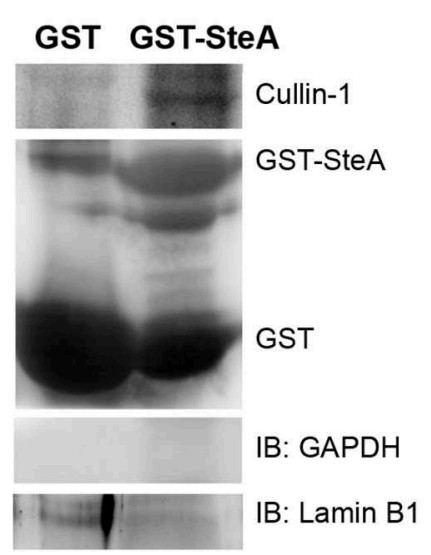

C IP: Cullin-1

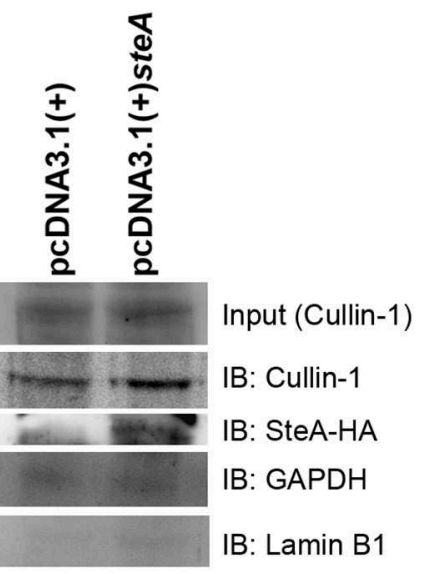

FIGURE 8 | SteA binds to Cullin-1. (A) SteA interacts with Cullin-1. The members of the Skp-1, Cullin-1, F-box (SCF) complex and steA were cloned in vectors containing activation domain (AD) and binding domain (BD), respectively, for the yeast two-hybrid screen. These were then cotransformed in yeast and selected on synthetic complete (SC)-Leu, SC-Ura, and SC-Leu, SC-Ura, SC-His plates and incubated for 2 days at $30^{\circ} \mathrm{C}$. The growth of yeast expressing Cullin-1 and SteA on SC-Leu, SC-Ura, and SC-His plates indicated interaction between SteA and Cullin-1. (B) Cullin-1 immunoprecipitates with SteA in the absence of stimulation. Whole-cell lysates of unstimulated RAW 264.7 cells were incubated with glutathione beads labeled with either GST-SteA or GST alone. The beads were then washed, and the proteins bound to GST-SteA or GST were analyzed by Western blotting using anti-Cullin-1 and anti-GST antibodies. (C) SteA interacts with Cullin-1. HEK 293 cells were transfected with pcDNA3.1(+)steA or pcDNA3.1(+) empty plasmid. After $36 \mathrm{~h}$ of transfection, whole-cell lysates were prepared following 30 min of tumor necrosis factor alpha (TNF $\alpha$ ) stimulation and immunoprecipitated with anti-Cullin-1 antibody. HA-tagged SteA was detected using anti-HA antibody. (B,C) Glyceraldehyde 3-phosphate dehydrogenase (GAPDH) and Lamin B1 were also probed after IP to check the specificity of the pulldowns.

lysates using anti-HA antibody following $\mathrm{TNF} \alpha$ stimulation. We have observed that the members of the SCF complex and I $\mathrm{B}$ coimmunoprecipitated with SteA (Figure 7C and Figure S3B). Furthermore, upon immunoprecipitation of RAW 264.7 cells infected with $\Delta$ steA and complemented strain expressing His-tagged SteA (compl-H) using anti-His antibody, we observed that SteA coimmunoprecipitated with the SCF complex as well as IKB (Figure 7D and Figure S3C) even upon infection.
These results indicated that SteA does not inhibit the binding of SCF complex to $\mathrm{I} \kappa \mathrm{B}$, and SteA itself binds to the IкBSCF complex.

\section{SteA Binds to Cullin-1}

To better understand how SteA suppresses IкB degradation, we wanted to explore with which component of the SCF complex SteA binds or whether it directly binds to IкB. Toward this, we did a yeast two-hybrid screen for the interaction of SteA 

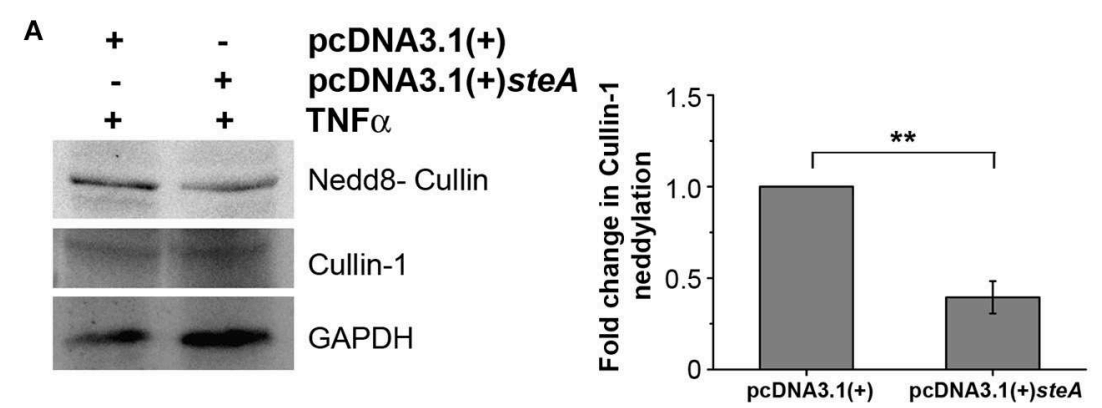

B

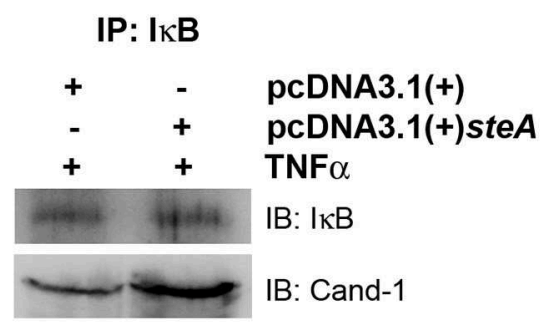

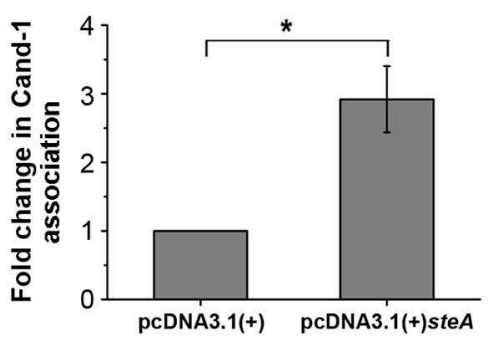

C GST GST-SteA

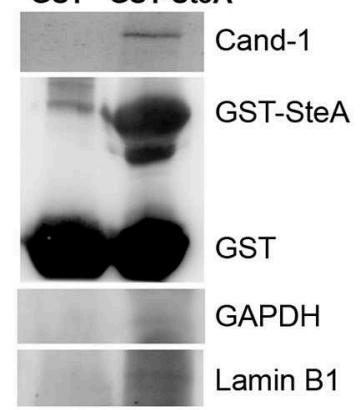

FIGURE 9 | SteA suppresses the neddylation of Cullin-1 and the dissociation of Cand-1. (A) Neddylation of Cullin is suppressed in mammalian cells endogenously expressing SteA. HEK 293 cells were transfected with pcDNA3.1(+)steA or pcDNA3.1(+) empty plasmid. After $24 \mathrm{~h}$ of transfection, whole-cell lysates were prepared following 30 min of tumor necrosis factor alpha (TNF $\alpha$ ) stimulation and analyzed by Western blotting using anti-nedd8-Cullin and anti-Cullin-1 antibodies and densitometry. Glyceraldehyde 3-phosphate dehydrogenase (GAPDH) was used as a loading control. (B) Cand-1 dissociation from SCF-E3 complex localized at IkB is decreased in the presence of SteA. HEK 293 cells were transfected with pcDNA3.1(+)steA or pcDNA3.1(+) empty plasmid. After $24 \mathrm{~h}$ of transfection, whole-cell lysates were prepared following 20 min of TNF $\alpha$ stimulation in the presence of proteasomal inhibitor (MG132) and immunoprecipitated with anti-lкB antibody. Cand-1 association was analyzed by Western blotting and densitometry. (A,B) For densitometric analysis, fold change was calculated with respect to empty plasmid transfected cells. Bar graphs represent mean \pm SEM from three independent experiments. $p$ values were calculated using Student's $t$ test $\left[{ }^{*} p<0.05,{ }^{* \star} p<0.01,{ }^{* \star *} p\right.$ $<0.001$, ns $p>0.05$ vs. pcDNA3.1(+) transfected cells]. (C) Cand-1 coimmunoprecipitates with SteA even in the unstimulated cells. Whole-cell lysates of unstimulated RAW 264.7 cells were incubated with glutathione beads labeled with either GST-SteA or GST alone. The beads were then washed, and the proteins bound to GST-SteA or GST were analyzed by Western blotting using anti-Cand-1 and anti-GST antibodies. GAPDH and Lamin B1 were also probed after IP to check the specificity of the pulldown.

with IKB and the members of the SCF complex (Figure 8A). In this screen, we observed that SteA binds to Cullin-1 but not to IкB, Rbx-1, or Skp-1, indicating that SteA directly interacts with Cullin-1.

Interestingly, we also observed colocalization of SteA with Cullin-1 in both $\mathrm{TNF} \alpha$-stimulated and unstimulated SteA-transfected HEK 293 cells using confocal microscopy, suggesting an association of SteA with Cullin-1 even when SCF complex is not assembled at IкB (Figure S5A). Furthermore, we did a GST pulldown assay in whole-cell lysates of unstimulated RAW 264.7 cells using GST-tagged SteA and observed that Cullin-1 was coimmunoprecipitated with GST-tagged SteA (Figure 8B and Figure S4B). In addition, in HEK 293 cells expressing HA-tagged SteA, we observed that SteA coimmunoprecipitated with Cullin-1 upon immunoprecipitation with anti-Cullin-1 antibody (Figure 8C and Figure S4A).

Altogether, these data confirmed that SteA interacts with Cullin-1 to suppress I $\mathrm{B}$ degradation.

\section{SteA Binds to Cullin-1 and Prevents Its Neddylation by Interfering With the Dissociation of Cand-1 From Cullin-1}

Generally, upon assembly of the SCF complex to IкB, Cullin1 gets neddylated. This neddylation of Cullin-1 is a crucial step for the activation of the SCF-E3 ligase, which leads to the ubiquitination of IкB (39). Upon neddylation, Cand-1, which is bound to Cullin-1 in the inactivated state, is removed from the E3 ligase complex (40). Therefore, we first checked the neddylation of Cullin-1 in HEK 293 cells transfected with pcDNA3.1(+) and pcDNA3.1(+)steA and observed that, upon TNF $\alpha$ stimulation, Cullin-1 was less neddylated in cells expressing SteA (Figure 9A). Furthermore, to check if Cand-1 dissociation from the E3 ligase complex was inhibited in the presence of SteA, we stimulated SteA-expressing HEK 293 cells after pretreatment with MG132 and immunoprecipitated with anti-IкB antibody and probed for Cand-1. We observed that Cand-1 dissociation was lesser in the presence of SteA (Figure 9B). In addition, in GST pulldown assay, we observed the association of Cand-1 to GST-tagged 


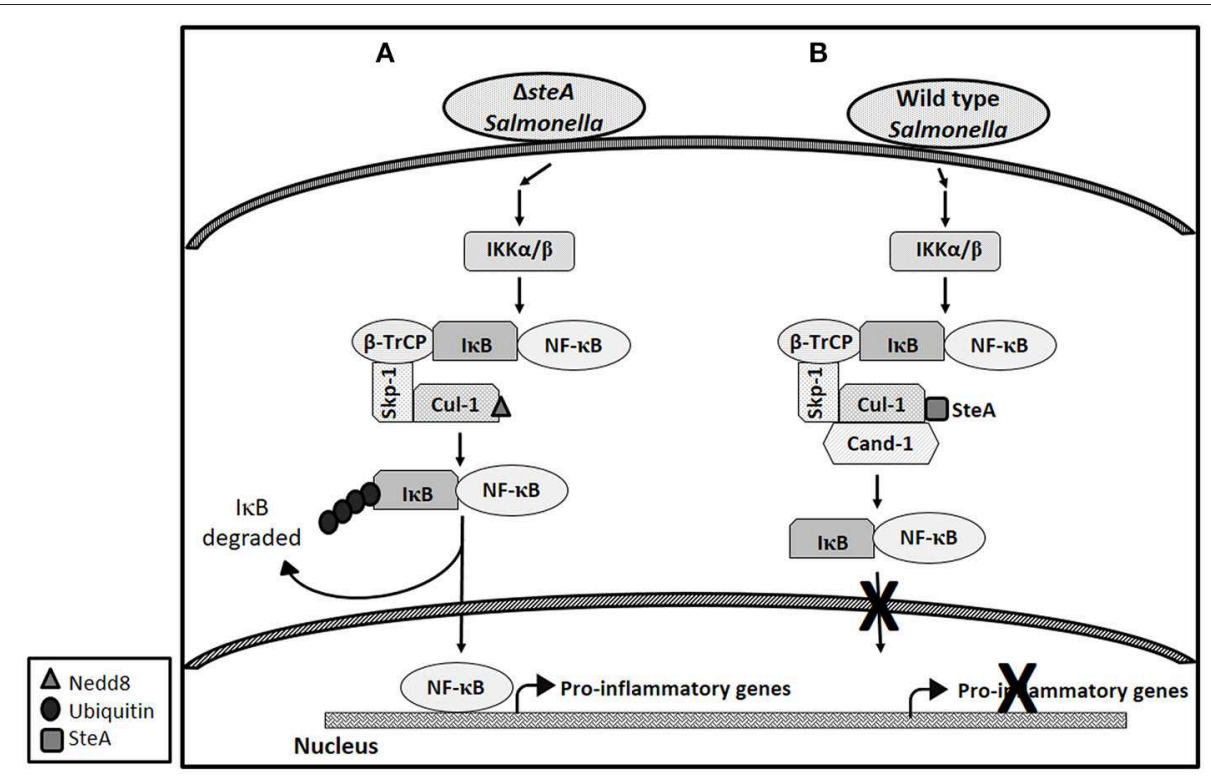

FIGURE 10 | Schematic representation of how SteA suppresses the nuclear factor kappa B (NF-кB) pathway. (A) In absence of SteA, Salmonella Typhimurium ( $\Delta$ steA) infection triggers a signaling cascade, which leads to the phosphorylation of $I \mathrm{KK} \alpha / \beta$. IKK $\alpha / \beta$ then phosphorylates $\mid \mathrm{KB}$, which is the inhibitor of $N F-\kappa B$. In the inactivated

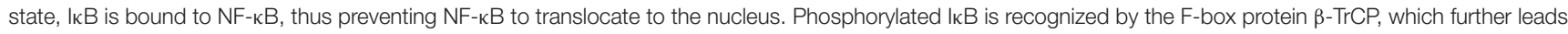
to recruitment of the Skp-1 and Cullin-1 (Cul-1) to form the SCF-E3 ligase complex. Cullin-1 is bound to Cand-1 in the inactive state, and upon neddylation, Cand-1 dissociates from Cullin-1 leading to the complete activation of the E3 ligase. The E3 ligase complex is responsible for the polyubiquitination of IkB. Upon polyubiquitination, IkB undergoes proteasomal degradation, rendering NF-kB free to translocate to the nucleus and transcribe proinflammatory genes. (B) During wild-type (wt) Salmonella Typhimurium infection (when SteA is present), SteA binds to Cullin-1 (of SCF-E3 ligase) and suppresses the neddylation of Cullin-1 and the dissociation of Cand-1 from Cullin-1, thereby suppressing the polyubiquitination of $\mathrm{\kappa} \mathrm{KB}$. This leads to the suppression of NF-kB-mediated proinflammatory responses.

SteA even in unstimulated RAW 264.7 cells, indicating that SteA remains associated with Cullin-1/Cand-1 complex even without stimulation (Figure 9C and Figure S4C). To further confirm this, we checked the colocalization of SteA and Cand-1 in SteAtransfected HEK 293 cells, and we observed no difference in the colocalization of SteA and Cand-1 with or without TNF $\alpha$ stimulation (Figure S5B).

Altogether, this study shows that SteA suppresses the immune responses of the host by suppressing the degradation of IкB. SteA prevents the degradation of I $\mathrm{B}$ by binding to Cullin1 and thus suppressing the neddylation of Cullin-1, which is necessary for the complete activation of the E3 ligase complex to ubiquitinate ІкB (Figure 10).

\section{DISCUSSION}

In response to a bacterial infection, the immune cells of the host elicit a proinflammatory response and signal other cells of the intrusion. This eventually leads to clearing of the bacteria from the host system. Some pathogens including Salmonella Typhimurium have been known to evade the immune system of the host and establish a niche in the macrophages. Salmonella Typhimurium makes use of some of the effectors that it translocates directly into the host cells via the type three secretion systems (T3SS) to suppress the host's immune responses. The effectors secreted by T3SSs, mainly T3SS-1, play different roles in immunomodulation of the host (8). Toward characterizing the T3SS-1 role of SteA, we found that mice infected with steA-deficient Salmonella Typhimurium $(\Delta s t e A)$ showed lower survival as compared to the wt Salmonella Typhimurium infected mice (Figures 1A,B). Furthermore, a higher immune response in mice infected with $\Delta$ steA seemed to be the cause of increased lethality (Figures 1C-E and Figure S1). Similarly, higher proinflammatory responses were observed when RAW 264.7 murine macrophage cell line and BMDMs were infected with $\triangle$ steA as compared to wt-infected cells (Figure 2A). Furthermore, we confirmed that SteA-mediated suppression of immune response is a T3SS-1 effect using a strain deficient in T3SS-2 ( $\Delta$ spi2) and a $\Delta$ spi2 $\Delta$ steA double mutant (Figure 2B).

The proinflammatory responses are mediated by a multistep signaling cascade involving the activation of the NF- $\kappa \mathrm{B}$ pathway or the MAP kinase pathway leading to the activation of transcription factors NF- $\kappa \mathrm{B}$ and AP-1 (36). Some of the effectors of Salmonella Typhimurium are already known to suppress the host-immune responses. For example, SpvC suppresses the MAP kinase pathway by dephosphorylating JNK and ERK (41), SptP acts on the ERK activation (42, 43), while AvrA suppresses both the NF- $\kappa$ B and the MAP kinase pathway (44-47), hence suppressing inflammation. To be able to understand how SteA suppresses the proinflammatory responses, we first checked the activation levels of p38 and JNK MAP kinases in the wholecell lysates and the levels of NF-кB family members (p65 and $\mathrm{c}-\mathrm{Rel}$ ) in the nuclear lysates. We observed that SteA does not affect the MAP-kinase activation but acts on the NF- $\kappa B$ pathway 
to suppress the immune responses (Figures 3-5). To confirm our observation, we transfected HEK 293 and RAW 264.7 cells with NF- $\kappa \mathrm{B}$ luciferase reporter plasmid and found the activation of NF-кB to be higher upon infection with $\Delta$ steA than the wt (Figure 5B). Furthermore, upon endogenous expression of SteA in HEK 293 cells, the NF- $\kappa$ B reporter activity was found to be suppressed (Figure 5C). Since suppression of the NF- $\mathrm{B}$ pathway is crucial for the survival of Salmonella Typhimurium in the host, Salmonella Typhimurium secretes various effectors to control it at multiple levels. In the inactive state, NF- $\mathrm{B}$ remains bound

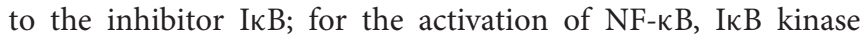
(IKK) phosphorylates I $\mathrm{B}$ and leads to its ubiquitination and degradation rendering NF- $\kappa \mathrm{B}$ free. The free NF- $\kappa \mathrm{B}$ transcription factor translocates to the nucleus, binds to the DNA, and upregulates transcription of inflammatory cytokine genes (37). Some effectors such as AvrA and SseL are known to interfere

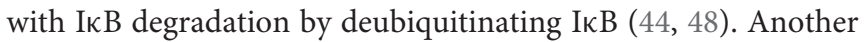
effector, SpvD, affects the recycling of NF- $\kappa$ B, and PipA acts as a protease, which cleaves RelA, a subunit of NF- $\kappa \mathrm{B}$ after its activation $(49,50)$. Toward exploring how SteA suppresses the NF- $\kappa \mathrm{B}$ pathway, we checked the degradation level of I $\mathrm{B}$ in the presence or absence of SteA and observed increased degradation of IкB in the absence of SteA compared to when SteA was present, suggesting that SteA acts on IкB degradation (Figure 4). The degradation of $I \kappa B$ is a multistep pathway which is initiated by the phosphorylation of ІкB. ІкB phosphorylation is dependent on IKK; therefore, there could be increased activation of IKK itself in the absence of SteA, but we observed comparable activation of IKK in cells infected with wt or $\Delta$ steA strains (Figure 6A). Following phosphorylation, the SCF-E3 ligase complex assembles on $\mathrm{I} \kappa \mathrm{B}$, leading to the polyubiquitination of $\mathrm{I} \kappa \mathrm{B}$ and hence its proteasomal degradation (31). One of the effectors, GogB, suppresses ubiquitination by acting on Skp-1, a component of SCF-E3 ligase (51). Our study indicated that SteA also binds to the SCF complex and suppresses the activation of IкB by interfering with the ubiquitination (Figure 6B). However, we observed that SteA mainly acts on Cullin-1 of SCF-E3 ligase complex (Figure 8). For ubiquitination to happen, the neddylation of Cullin-1 follows the assembly of SCF-E3 ligase complex to I $\kappa$ B. Neddylation of Cullin-1 is a crucial step for the complete activation of the E3 ligase (39). Cullin-1 in the inactive form remains bound to Cand-1; however, upon activation, Cand1 dissociates from Cullin-1 allowing neddylation to happen (40). Our study indicated that SteA binds to Cullin-1 (Figure 8), thus interfering with neddylation of Cullin-1 and the dissociation of Cand-1 from Cullin-1 (Figure 9). This further results in suppression of IкB ubiquitination and its degradation.

In response to Salmonella Typhimurium infection, proinflammatory responses are generated in the host. This immune response is capable of clearing the infection; also, if unchecked, it may be lethal for the host. However, for Salmonella Typhimurium to be able to survive and multiply in the host, these proinflammatory responses need to be suppressed. For this, Salmonella Typhimurium secretes an array of effectors which suppress the immune responses at multiple levels and ensures its survival in the host.

Altogether, our study shows that Salmonella Typhimurium effector SteA suppresses the proinflammatory responses generated against Salmonella Typhimurium by suppressing the neddylation of Cullin-1 and hence suppressing the degradation

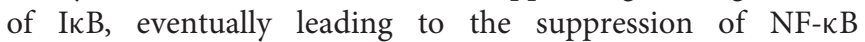
activation (Figure 10).

\section{DATA AVAILABILITY STATEMENT}

All datasets generated for this study are included in the article/Supplementary Material. The raw datasets will be available on request.

\section{ETHICS STATEMENT}

The animal study was reviewed and approved by the Institutional Animals Ethics Committee (IAEC) of the Indian Institute of Science Education and Research, Mohali.

\section{AUTHOR CONTRIBUTIONS}

AG designed and performed experiments, analyzed the data, and wrote the paper. RS performed experiments and analyzed the data. AM designed experiments, analyzed data, supervised the study, and wrote the paper.

\section{FUNDING}

This work was funded by a research grant from the Science and Engineering Research Board (SERB), Department of Science and Technology (DST), India (Grant No. EMR/2016/007788) and IISER Mohali. We acknowledge the Indian Council of Medical Research (ICMR) for funding AG and IISER Mohali for funding RS.

\section{ACKNOWLEDGMENTS}

We thank Dr. Rachna Chaba (IISER Mohali, India) and her lab members for helping us with the preparation of deletion mutants and Dr. Shravan K. Mishra (IISER Mohali, India) and his lab members for helping with yeast two-hybrid-based experiments. We thank Dr. Kausik Chattopadhyay, Dr. Mahak Sharma, Dr. Rajesh Ramachandran, and Dr. Ram K. Yadav from IISER Mohali, India, and Dr. Francisco Ramos-Morales from the University of Seville, Spain for providing us with various strains or plasmids.

\section{SUPPLEMENTARY MATERIAL}

The Supplementary Material for this article can be found online at: https://www.frontiersin.org/articles/10.3389/fimmu. 2019.02822/full\#supplementary-material 


\section{REFERENCES}

1. Kubori T, Matsushima Y, Nakamura D, Uralil J, Lara-Tejero M, Sukhan A, et al. Supramolecular structure of the Salmonella typhimurium type III protein secretion system. Science. (1998) 280:602-5. doi: $10.1126 /$ science.280.5363.602

2. Galan JE. Interaction of Salmonella with host cells through the centisome 63 type III secretion system. Curr Opin Microbiol. (1999) 2:46-50. doi: 10.1016/S1369-5274(99)80008-3

3. Galan JE. Molecular genetic bases of Salmonella entry into host cells. $\mathrm{Mol}$ Microbiol. (1996) 20:263-71. doi: 10.1111/j.1365-2958.1996.tb02615.x

4. Ochman H, Soncini FC, Solomon F, Groisman EA. Identification of a pathogenicity island required for Salmonella survival in host cells. Proc Natl Acad Sci USA. (1996) 93:7800-4. doi: 10.1073/pnas.93.15.7800

5. Shea JE, Hensel M, Gleeson C, Holden DW. Identification of a virulence locus encoding a second type III secretion system in Salmonella typhimurium. Proc Natl Acad Sci USA. (1996) 93:2593-7. doi: 10.1073/pnas.93.6.2593

6. Ramos-Morales F. Impact of Salmonella enterica type III secretion system effectors on the eukaryotic host cell. ISRN Cell Biol. (2012) 2012:36. doi: $10.5402 / 2012 / 787934$

7. Hensel M, Shea JE, Waterman SR, Mundy R, Nikolaus T, Banks $G$, et al. Genes encoding putative effector proteins of the type III secretion system of Salmonella pathogenicity island 2 are required for bacterial virulence and proliferation in macrophages. Mol Microbiol. (1998) 30:163-74. doi: 10.1046/j.1365-2958.1998. 01047.x

8. McGhie EJ, Brawn LC, Hume PJ, Humphreys D, Koronakis V. Salmonella takes control: effector-driven manipulation of the host. Curr Opin Microbiol. (2009) 12:117-24. doi: 10.1016/j.mib.2008.12.001

9. Eichelberg K, Galan JE. Differential regulation of Salmonella typhimurium type III secreted proteins by pathogenicity island 1. (SPI-1)-encoded transcriptional activators InvF and hilA. Infect Immun. (1999) 67:4099-105.

10. McGhie EJ, Hayward RD, Koronakis V. Cooperation between actin-binding proteins of invasive Salmonella: SipA potentiates SipC nucleation and bundling of actin. EMBO J. (2001) 20:2131-9. doi: 10.1093/emboj/20. 9.2131

11. Lilic M, Galkin VE, Orlova A, VanLoock MS, Egelman EH, Stebbins CE. Salmonella SipA polymerizes actin by stapling filaments with nonglobular protein arms. Science. (2003) 301:1918-21. doi: 10.1126/science.1088433

12. Myeni SK, Zhou D. The C terminus of SipC binds and bundles Factin to promote Salmonella invasion. J Biol Chem. (2010) 285:13357-63. doi: 10.1074/jbc.M109.094045

13. Friebel A, Ilchmann H, Aepfelbacher M, Ehrbar K, Machleidt W, Hardt WD. SopE and SopE2 from Salmonella typhimurium activate different sets of RhoGTPases of the host cell. J Biol Chem. (2001) 276:34035-40. doi: 10.1074/jbc.M100609200

14. Hapfelmeier S, Ehrbar K, Stecher B, Barthel M, Kremer M, Hardt WD. Role of the Salmonella pathogenicity island 1 effector proteins SipA, SopB, SopE, and SopE2 in Salmonella enterica subspecies 1 serovar Typhimurium colitis in streptomycin-pretreated mice. Infect Immun. (2004) 72:795-809. doi: 10.1128/IAI.72.2.795-809.2004

15. Bruno VM, Hannemann S, Lara-Tejero M, Flavell RA, Kleinstein SH, Galan JE. Salmonella typhimurium type III secretion effectors stimulate innate immune responses in cultured epithelial cells. PLoS Pathog. (2009) 5:e1000538. doi: 10.1371/journal.ppat.1000538

16. Stein MA, Leung KY, Zwick M, Garcia-del Portillo F, Finlay BB. Identification of a Salmonella virulence gene required for formation of filamentous structures containing lysosomal membrane glycoproteins within epithelial cells. Mol Microbiol. (1996) 20:151-64. doi: 10.1111/j.1365-2958.1996.tb02497.x

17. Beuzon CR, Meresse S, Unsworth KE, Ruiz-Albert J, Garvis S, Waterman SR, et al. Salmonella maintains the integrity of its intracellular vacuole through the action of SifA. EMBO J. (2000) 19:3235-49. doi: 10.1093/emboj/19.13.3235

18. Brumell JH, Goosney DL, Finlay BB. SifA, a type III secreted effector of Salmonella typhimurium, directs Salmonella-induced filament. (Sif) formation along microtubules. Traffic. (2002) 3:407-15. doi: 10.1034/j.1600-0854.2002.30604.x
19. Brumell JH, Tang P, Mills SD, Finlay BB. Characterization of Salmonellainduced filaments. (Sifs) reveals a delayed interaction between Salmonellacontaining vacuoles and late endocytic compartments. Traffic. (2001) 2:64353. doi: 10.1034/j.1600-0854.2001.20907.x

20. Vorwerk S, Krieger V, Deiwick J, Hensel M, Hansmeier N. Proteomes of host cell membranes modified by intracellular activities of Salmonella enterica. Mol Cell Proteom. (2015) 14:81-92. doi: 10.1074/mcp.M114.041145

21. Knuff K, Finlay BB. What the SIF is happening-the role of intracellular salmonella-induced filaments. Front Cell Infect Microbiol. (2017) 7:335. doi: $10.3389 /$ fcimb.2017.00335

22. Geddes K, Worley M, Niemann G, Heffron F. Identification of new secreted effectors in Salmonella enterica serovar Typhimurium. Infect Immun. (2005) 73:6260-71. doi: 10.1128/IAI.73.10.6260-6271.2005

23. Niemann GS, Brown RN, Gustin JK, Stufkens A, Shaikh-Kidwai AS, Li J, et al. Discovery of novel secreted virulence factors from Salmonella enterica serovar Typhimurium by proteomic analysis of culture supernatants. Infect Immun. (2011) 79:33-43. doi: 10.1128/IAI.00771-10

24. Cardenal-Munoz E, Ramos-Morales F. Analysis of the expression, secretion and translocation of the Salmonella enterica type III secretion system effector SteA. PLoS ONE. (2011) 6:e26930. doi: 10.1371/journal.pone.0026930

25. Lawley TD, Chan K, Thompson LJ, Kim CC, Govoni GR, Monack DM. Genome-wide screen for Salmonella genes required for longterm systemic infection of the mouse. PLoS Pathog. (2006) 2:e11. doi: 10.1371/journal.ppat.0020011

26. Van Engelenburg SB, Palmer AE. Imaging type-III secretion reveals dynamics and spatial segregation of Salmonella effectors. Nat Methods. (2010) 7:325-30. doi: $10.1038 /$ nmeth. 1437

27. Domingues L, Holden DW, Mota LJ. The Salmonella effector SteA contributes to the control of membrane dynamics of Salmonella-containing vacuoles. Infect Immun. (2014) 82:2923-34. doi: 10.1128/IAI.01385-13

28. Domingues L, Ismail A, Charro N, Rodriguez-Escudero I, Holden DW, Molina M, et al. The Salmonella effector SteA binds phosphatidylinositol 4phosphate for subcellular targeting within host cells. Cell Microbiol. (2016) 18:949-69. doi: 10.1111/cmi.12558

29. Matsuda S, Haneda T, Saito H, Miki T, Okada N. Salmonella enterica Effectors SifA, SpvB, SseF, SseJ, and SteA contribute to type III secretion system 1independent inflammation in a streptomycin-pretreated mouse model of colitis. Infect Immun. (2019) 87:e00872-18. doi: 10.1128/IAI.00872-18

30. McQuate SE, Young AM, Silva-Herzog E, Bunker E, Hernandez M, de Chaumont $\mathrm{F}$, et al. Long-term live-cell imaging reveals new roles for Salmonella effector proteins SseG and SteA. Cell Microbiol. (2017) 19:e12641. doi: $10.1111 / \mathrm{cmi} .12641$

31. Kanarek N, London N, Schueler-Furman O, Ben-Neriah Y. Ubiquitination and degradation of the inhibitors of NF-kappaB. Cold Spring Harb Perspect Biol. (2010) 2:a000166. doi: 10.1101/cshperspect.a000166

32. Datsenko KA, Wanner BL. One-step inactivation of chromosomal genes in Escherichia coli K-12 using PCR products. Proc Natl Acad Sci USA. (2000) 97:6640-5. doi: 10.1073/pnas.120163297

33. Baison-Olmo F, Cardenal-Munoz E, Ramos-Morales F. PipB2 is a substrate of the Salmonella pathogenicity island 1-encoded type III secretion system. Biochem Biophys Res Commun. (2012) 423:240-6. doi: 10.1016/j.bbrc.2012.05.095

34. Shrum B, Anantha RV, Xu SX, Donnelly M, Haeryfar SM, McCormick JK, et al. A robust scoring system to evaluate sepsis severity in an animal model. BMC Res Notes. (2014) 7:233. doi: 10.1186/1756-0500-7-233

35. Mai SHC, Sharma N, Kwong AC, Dwivedi DJ, Khan M, Grin PM, et al Body temperature and mouse scoring systems as surrogate markers of death in cecal ligation and puncture sepsis. Intensive Care Med Exp. (2018) 6:20. doi: 10.1186/s40635-018-0184-3

36. Kawai $\mathrm{T}$, Akira $\mathrm{S}$. The role of pattern-recognition receptors in innate immunity: update on Toll-like receptors. Nat Immunol. (2010) 11:373-84. doi: 10.1038/ni. 1863

37. Oeckinghaus A, Ghosh S. The NF-kappaB family of transcription factors and its regulation. Cold Spring Harb Perspect Biol. (2009) 1:a000034. doi: 10.1101/cshperspect.a000034

38. Deshaies RJ. SCF and Cullin/Ring H2-based ubiquitin ligases. Annu Rev Cell Dev Biol. (1999) 15:435-67. doi: 10.1146/annurev.cellbio.15.1.435 
39. Petroski MD, Deshaies RJ. Function and regulation of cullin-RING ubiquitin ligases. Nat Rev Mol Cell Biol. (2005) 6:9-20. doi: 10.1038/nrm1547

40. Goldenberg SJ, Cascio TC, Shumway SD, Garbutt KC, Liu J, Xiong Y, et al. Structure of the Cand1-Cul1-Rocl complex reveals regulatory mechanisms for the assembly of the multisubunit cullin-dependent ubiquitin ligases. Cell. (2004) 119:517-28. doi: 10.1016/j.cell.2004.10.019

41. Mazurkiewicz P, Thomas J, Thompson JA, Liu M, Arbibe L, Sansonetti P, et al. SpvC is a Salmonella effector with phosphothreonine lyase activity on host mitogen-activated protein kinases. Mol Microbiol. (2008) 67:1371-83. doi: 10.1111/j.1365-2958.2008.06134.x

42. Murli S, Watson RO, Galan JE. Role of tyrosine kinases and the tyrosine phosphatase SptP in the interaction of Salmonella with host cells. Cell Microbiol. (2001) 3:795-810. doi: 10.1046/j.1462-5822.2001.00158.x

43. Lin SL, Le TX, Cowen DS. SptP, a Salmonella typhimurium type III-secreted protein, inhibits the mitogen-activated protein kinase pathway by inhibiting Raf activation. Cell Microbiol. (2003) 5:267-75. doi: 10.1046/j.1462-5822.2003.t01-1-00274.x

44. Collier-Hyams LS, Zeng H, Sun J, Tomlinson AD, Bao ZQ, Chen H, et al. Cutting edge: salmonella AvrA effector inhibits the key proinflammatory, anti-apoptotic NF-kappa B pathway. J Immunol. (2002) 169:2846-50. doi: 10.4049/jimmunol.169.6.2846

45. Ye Z, Petrof EO, Boone D, Claud EC, Sun J. Salmonella effector AvrA regulation of colonic epithelial cell inflammation by deubiquitination. Am J Pathol. (2007) 171:882-92. doi: 10.2353/ajpath.2007.070220

46. Jones RM, Wu H, Wentworth C, Luo L, Collier-Hyams L, Neish AS. Salmonella AvrA coordinates suppression of host immune and apoptotic defenses via JNK pathway blockade. Cell Host Microbe. (2008) 3:233-44. doi: 10.1016/j.chom.2008.02.016

47. Du F, Galan JE. Selective inhibition of type III secretion activated signaling by the Salmonella effector AvrA. PLoS Pathog. (2009) 5:e1000595. doi: 10.1371/journal.ppat.1000595
48. Le Negrate G, Faustin B, Welsh K, Loeffler M, Krajewska M, Hasegawa P, et al. Salmonella secreted factor L deubiquitinase of Salmonella typhimurium inhibits NF-kappaB, suppresses IkappaBalpha ubiquitination and modulates innate immune responses. J Immunol. (2008) 180:5045-56. doi: 10.4049/jimmunol.180. 7.5045

49. Rolhion N, Furniss RC, Grabe G, Ryan A, Liu M, Matthews SA, et al Inhibition of nuclear transport of NF-kB p65 by the Salmonella type III secretion system effector SpvD. PLoS Pathog. (2016) 12:e1005653. doi: 10.1371/journal.ppat.1005653

50. Sun H, Kamanova J, Lara-Tejero M, Galan JE. A family of salmonella type III secretion effector proteins selectively targets the NF-kappaB signaling pathway to preserve host homeostasis. PLoS Pathog. (2016) 12:e1005484. doi: 10.1371/journal.ppat.1005484

51. Pilar AV, Reid-Yu SA, Cooper CA, Mulder DT, Coombes BK. GogB is an anti-inflammatory effector that limits tissue damage during Salmonella infection through interaction with human FBXO22 and Skp1. PLoS Pathog. (2012) 8:e1002773. doi: 10.1371/journal.ppat.10 02773

Conflict of Interest: The authors declare that the research was conducted in the absence of any commercial or financial relationships that could be construed as a potential conflict of interest.

Copyright $(\odot 2019$ Gulati, Shukla and Mukhopadhaya. This is an open-access article distributed under the terms of the Creative Commons Attribution License (CC BY). The use, distribution or reproduction in other forums is permitted, provided the original author(s) and the copyright owner(s) are credited and that the original publication in this journal is cited, in accordance with accepted academic practice. No use, distribution or reproduction is permitted which does not comply with these terms. 